A POTASSIUM-STEAM BINARY VAPOR CYCLE

FOR NUCLEAR POWER PLANTS

W. R. Chambers

A. P. Fraas

M. N. Ozisik

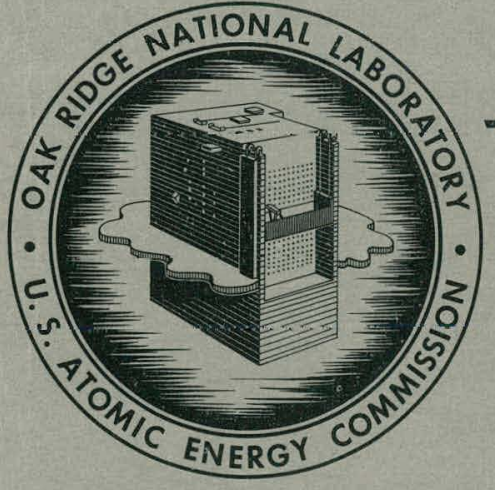

OAK RIDGE NATIONAL LABORATORY

operated by

UNION CARBIDE CORPORATION

for the

U.S. ATOMIC ENERGY COMMISSION 


\section{DISCLAIMER}

This report was prepared as an account of work sponsored by an agency of the United States Government. Neither the United States Government nor any agency Thereof, nor any of their employees, makes any warranty, express or implied, or assumes any legal liability or responsibility for the accuracy, completeness, or usefulness of any information, apparatus, product, or process disclosed, or represents that its use would not infringe privately owned rights. Reference herein to any specific commercial product, process, or service by trade name, trademark, manufacturer, or otherwise does not necessarily constitute or imply its endorsement, recommendation, or favoring by the United States Government or any agency thereof. The views and opinions of authors expressed herein do not necessarily state or reflect those of the United States Government or any agency thereof. 


\section{DISCLAIMER}

Portions of this document may be illegible in electronic image products. Images are produced from the best available original document. 


\subsection{0}

Printed in USA. Price: \$125 Available from the

Office of Technical Services

U. S. Department of Commerce

Washington 25, D. C.

LEGAL NOTICE

This report was prepared as an account of Government sponsored work. Neither the United States, nor the Commission, nor any person acting on behalf of the Commission:

A. Makes any warranty or representation, expressed or implied, with respect to the accuracy, completeness, or usefulness of the information contoined in this report, or that the use of any information, apparatus, method, or process disclosed in this report may not infringe privately owned rights; or

B. Assumes any liabilities with respect to the use of, or for damages resulting from the use of any information, apparatus, method, or process disclosed in this report.

As used in the above, "person acting on behalf of the Commission" includes any employee or contractor of the Commission, or employee of such contractor, to the extent that such employee or contractor of the Commission, or emplayee of such contractor prepares, disseminates, or provides access to, any information pursuant to his employment or contract with the Commission, or his employment with such contractor. 
ORNL-3584

Contract No. W-7405-eng-26

\begin{abstract}
Reactor Division
A POTASSIUM-STEAM BIIVARY VAPOR CYCIE FOR NUCLEAR POWER PLANTS
\end{abstract}

W. R. Chambers A. P. Fraas

M. N. Ozisik

MAY 1964

OAK RIDGE NATIONAL IABORATORY

Oak Ridge, Tennessee

operated by

UNION CARBIDE CORPORATION

for the

IT. S. ATOMIC ENERGY COMMISSION 


\section{THIS PAGE \\ WAS INTENTIONALLY \\ LEFT BLANK}




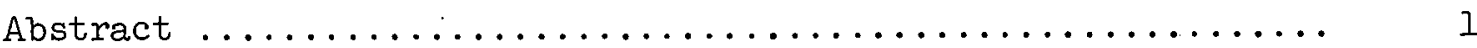

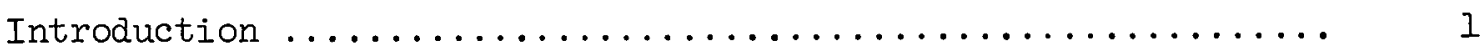

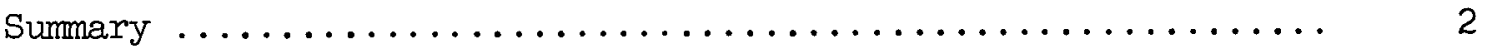

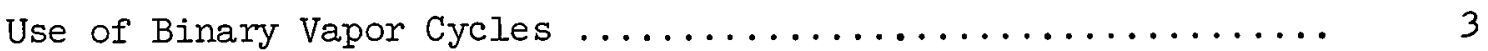

Background of Experience with Binary Vapor Cycles ........... 4

Use of Supercritical-Pressure Steam Systems .............. 8

General Design Considerations ...................... 9

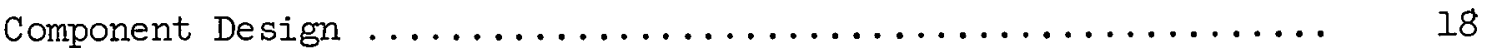

Reactor Core and Heat Exchanger Assembly .............. 18

Potassium Boiler, Turbine, and Condenser Units .......... 20

Shaft Seals $\ldots \ldots \ldots \ldots \ldots \ldots \ldots \ldots \ldots \ldots \ldots \ldots \ldots \ldots \ldots \ldots \ldots \ldots$

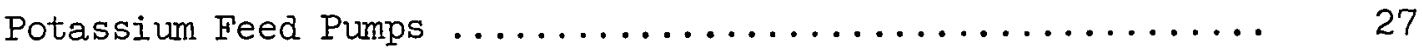

Regenerative Feed Hedting for the Potassium ............ 28

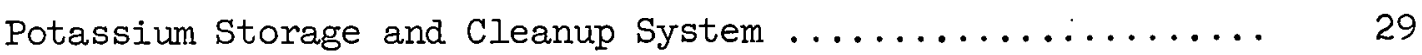

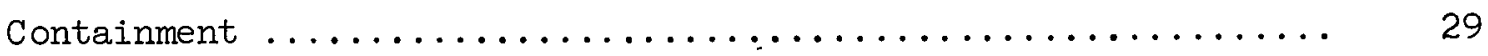

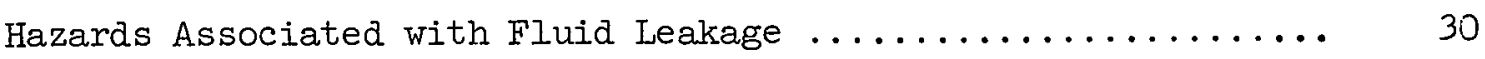

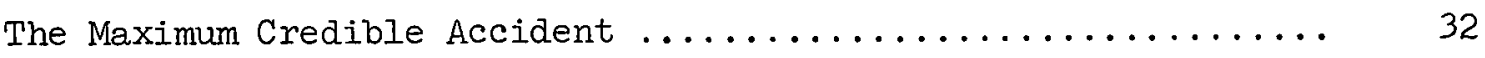

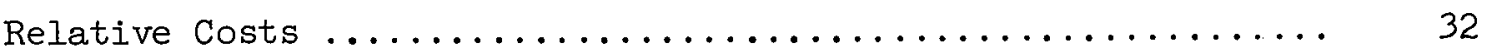

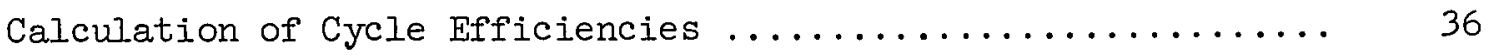

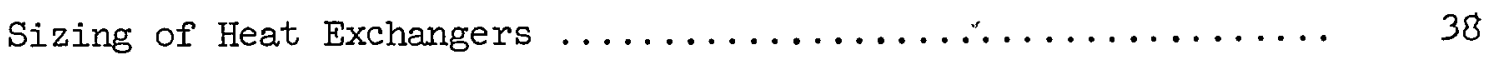

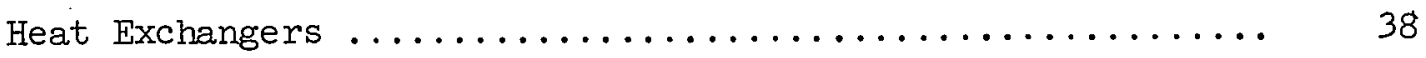

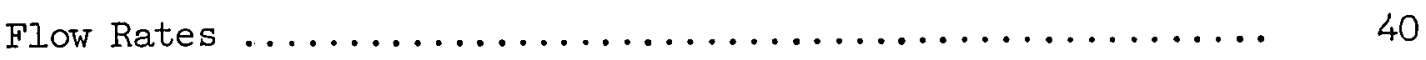

Heat Iransfer and Pressure Drop .................. 42

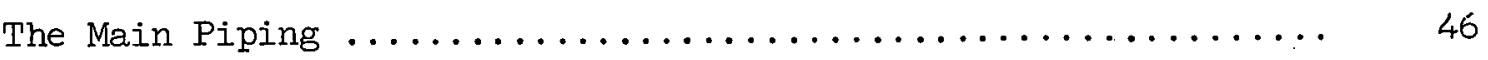

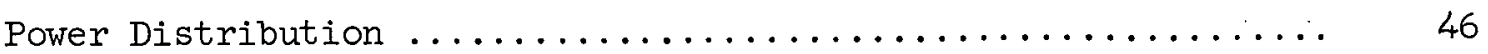

References ................................ 49 


\title{
A POTASSTUM-STEAM BINARY VAPOR CYCLE FOR NUCLEAR POWER PLANTS
}

\author{
W. R. Chambers A. P. Fraas \\ M. N. Ozisik
}

\begin{abstract}
The basic factors limiting the efficiency of both conventional steam power plants and mercury-vapor and steam binary cycle plants are discussed relative to the potential of a potassium-vapor and steam cycle for nuclear power plant applications. A conceptual design for one embodiment of the latter coupled to a molten-salt reactor is described. Its thermal efficiency is estimated to be 54\%, and the associated calculations, including those for the size of the principal components, are appended. The quantities of material required for the heat exchangers and piping for both a coalfired supercritical-pressure steam plant and a nuclear-powered potassium vapor and supercritical-steam plant are estimated along with the associated costs. The resulting cost and performance data indicate that the nuclear plant with a potassium-vapor and steam binary cycle could give both lower capital charges and a much higher overall efficiency than a coal-fired supercritical-pressure steam plant.
\end{abstract}

\section{Introduction}

Since the inception of ORNL work on space power plants in 1958, the possibility of coupling a nuclear reactor to a potassium-vapor cycle from which the waste heat would be rejected to a steam cycle has seemed attractive. This arrangement would achieve the advantages of the mercurysteam binary vapor cycle and yet avoid both the relatively high pressures and the mass transfer problems of a mercury system for the 1100 to $1500^{\circ} \mathrm{F}$ temperature range. It would be capable of an overall thermal efficiency of around 54\%, thus cutting not only the fuel and capital costs but also the condenser cooling-water requirement. The latter would be reduced to about half that of a conventional steam plant, a major advantage for many power plant locations either on rivers or in arid areas where cooling towers are required. Many of our rivers are now showing significant temperature increases in summer because of the many power plants along their. courcce, and the cituation will grow worce in the yearc to come. 
An attempt to lay out a system utilizing a binary vapor cyle was made early in 1959, but there were so many uncertainties that further work was deferred. Sufficient experience has now been gained from basic tests on boiling heat transfer, materials compatibility, and key components for potassium-vapor-cycle space power plants to make possible a preliminary design with enough detail to give a fairly good idea of the sizes of the major pieces of equipment and of the quantities of fuel, working fluids, and expensive alloys required for the system. This design study was prepared to indicate the form that such a system might take for a plant to be built about $1980^{\circ}$, its advantages, and something of the problems involved.

\section{Summary}

To illustrate the problems involved and the size of the major items of equipment, it was decided to base the design on a plant that would employ a molten-salt reactor with a fuel outlet temperature of $1800^{\circ} \mathrm{F}$. This would deliver heat through an intermediate heat exchanger to an inert salt at $1700^{\circ} \mathrm{F}$, which would, in turn, heat a potassium boiler that would deliver potassium vapor to a turbine at $1540^{\circ} \mathrm{F}$. A $100^{\circ} \mathrm{F}$ temperature drop would be taken in each of the two salt circuits. The potassium vapor leaving the turbine would condense at $1100^{\circ} \mathrm{F}$, and the heat of condensation would be transferred directly to generate steam at $4000 \mathrm{psi}$ and $1050^{\circ} \mathrm{F}$ with two reheats to $1050^{\circ} \mathrm{F}$ (these steam conditions are those of the second supercritical unit at the Philadelphia Electric Company Eddystone plant, which has an outstanding service record).

The structural materials in both salt circuits would be a refractory alloy something like the columbium-1\% zirconium alloy that has been given much attention in recent years. The potassium system would employ stainless steel throughout, except for the tubes in the potassium boiler, which would be made of the refractory alloy.

The principal basic feasibility questions for the system are associated with the corrosion of the refractory alloy by both the fuel salt and the inert salt in the intermediate circuit and the compatibility of the refractory alloy with boiling potassium in a stainless steel system where 
mass transfer might be a problem. This design study indicates that the merits of the power plant proposed are sufficient to justify some research to evaluate its feasibility.

The basic concept is also applicable to other reactor types, e.g., a sodium- or potassium-cooled fast reactor. A boiling-potassium reactor is a particularly interesting possibility, since it would make it possible to build the entire system of stainless steel and to eliminate the intermediate heat exchangers if a substantial amount of radioactivity could be tolerated in the potassium turbines. A preliminary design for such a plant must await the results of the MPRE development program. While, in principle, the cycle could be applied to a fossil-fueled plant, air-side corrosion would probably make this impracticable, particularly since the poor heat transfer coefficient on the air side would make it necessary to use a large quantity of expensive high-alloy materials in the potassium boiler.

\section{Use of Binary Vapor Cycles}

As the peak temperatures of Rankine cycles have been increased in an effort to improve cycle efficiency, the large increases in pressure have posed difficult problems. These have proved particularly onerous because the strengths of the structural alloys available fall off with increasing temperature. An obvious way to ease the problem is to employ two working fluids having widely different vapor pressures in two stages. A heat exchanger between the two would serve as both the condenser for the lowvapor-pressure fluid in the higher temperature portion of the cycle and as the boiler for the high-vapor-pressure fluid in the lower temperature portion of the cycle. This arrangement not only serves to reduce the pressure (and stresses) in the highest temperature portions of the system, but it has the further advantage that the proportions of the turbines become more reasonable - in a conventional steam system the low-pressure turbine with a discharge pressure of about l-in. Hg abs is large and awkward, while the very-high-pressure turbines are so small that tip clearance losses are a problem. Since steam systems built of iron-chromiumnickel alloys are limited by steam-side corrosion to the temperature range 
below about $1300^{\circ} \mathrm{F}$, this limitation can also be avoided by the proper choice of the working fluid for the high-temperature cycle.

The importance of the limitations on the development of conventional steam power plants is indicated by Fig. 1 (refs. 1 and 2), which shows that, while the operating temperatures of new steam plants increased steadily throughout the first half of this century, the increase has essentially stopped for the past decade, and, for the reasons cited above, there seems little likelihood that it will resume. Efforts toward improvements in cycle et'ticiency are centered on refinements, such as supercritical-pressure systems, multiple stages of reheat, and larger numbers of stages in the regenerative feedwater heating system. The further improvements in overall thermal ef't'iciency obtainable from any of these are inherently quite small.

\section{Background of Experience with Binary Vapor Cycles}

The advantages of a binary vapor cycle for power generation have been recognized for a long time, and mercury was one of the first fluids to be considered for this purpose. ${ }^{3}$ Since about 1913, experience in operating mercury systems has been accumulating, the first mercury-vapor turbinegenerator unit having been started up in 1917. A total of six other mercury vapor and steam power plants have since been built. 4,5,6 At present, the only one of these still operating is the Schiller plant of the Public Service Company at Portsmouth, N. H. ${ }^{7}$ While the mercury-steam binary cycle showed a favorable economy in the 1920's when the maximum steam pressures were of the order of $450 \mathrm{psi}$ and the capacity of turbine-generator units was much smaller than at present, conditions are much different today. The Schiller plant, when first built in 1949, was in a unique position in that it was in an area where there was a need for a relatively small capacity plant and the fuel costs were high. The mercury-steam unit was the first to be installed in the Schiller plant, and it was put into commercial operation with a design rating of $125 \mathrm{psia}$ and $960^{\circ} \mathrm{F}$ at the inlet to the mercury turbines. ${ }^{2}, 8$ The rated capacity is 15,000 kw for the two mercury units, which exhaust into a mercury condenser and steam boiler that feeds a steam turbine having a capacity of $25,000 \mathrm{kw}$. The total plant cost was 


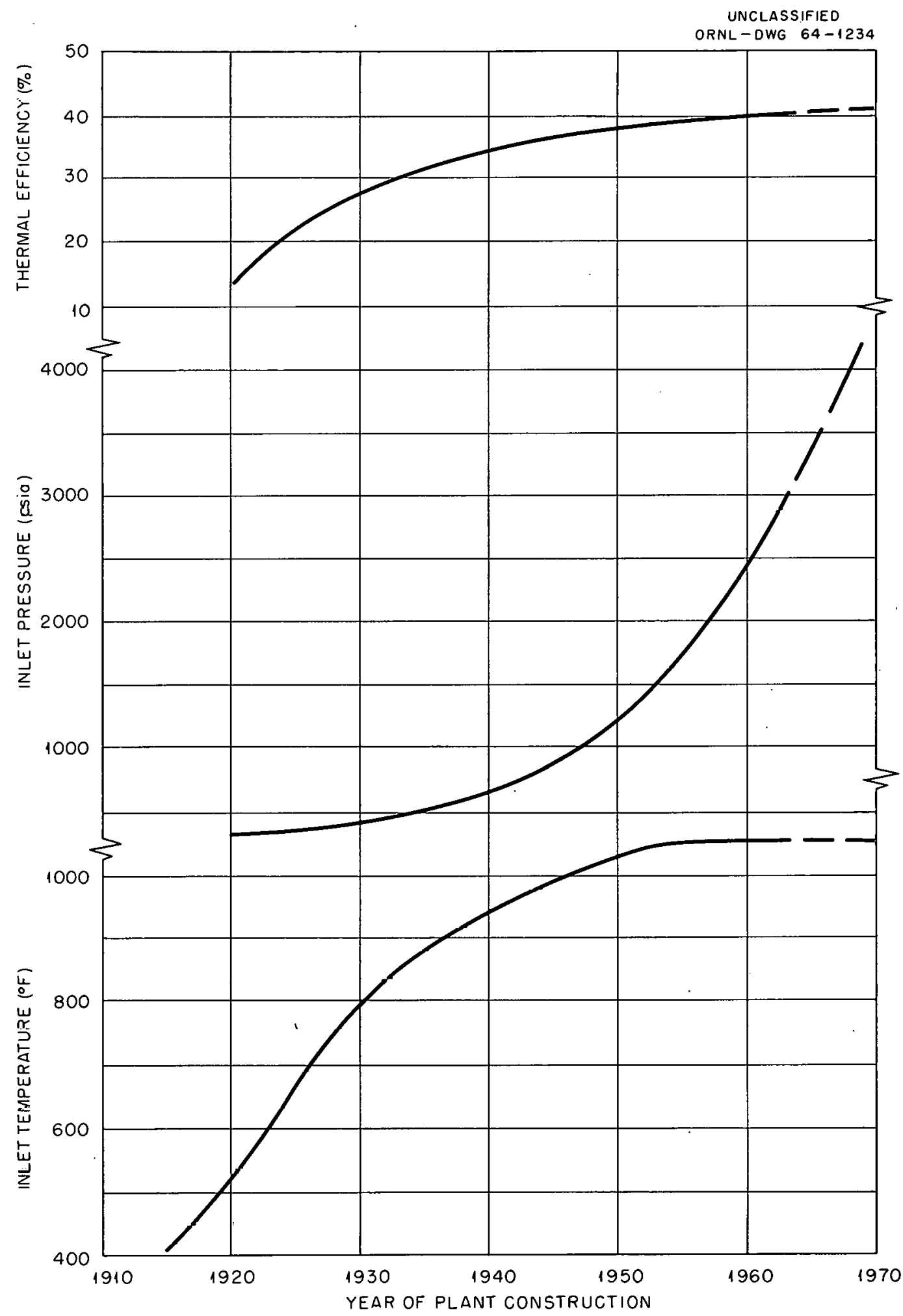

Fig. 1. Thermal Efficiency and Turbine Inlet Temperature and Pressure for the United States Steam Power Plants as a Function of the Year of Construction. (Data replotted from refs. 1 and 2.) 
$\$ 12,700,000$ or $\$ 317$ per $\mathrm{kw}$. The plant has been in continuous commercial operation for over 10 years. According to the Federal Power Commission Report, ${ }^{8}$ the heat rate averages $9700 \mathrm{Btu}$, giving an overall plant efficiency of 36.3\%. The Schiller plant has been enlarged to its present capacity of $190,000 \mathrm{kw}$ by the addition of standard steam turbine units of about 40,000 kw each, with a heat rate of about $11,000 \mathrm{Btu}$ per $\mathrm{kw}$ or $31 \%$ overall efficiency at a cost of $\$ 140$ per $k w$.

While the thermodynamic properties of mercury are well suited to the temperature range that was attractive in the $1920^{\prime} \mathrm{s}$, both high pressures and corrosion problems at temperatures above $950^{\circ} \mathrm{F}$ make mercury unattractive for use with the supercritical-pressure, high-temperature steam systems now in common use. Further, the poor wetting characteristics of mercury make it necessary to employ heat transfer rates about 15 or $20 \%$ of those commonly employed in steam boilers, thus increasing the size and cost of both the mercury boiler and the mercury condenser. While it was found in the early 1920's that the wetting difficulties could be overcome to some extent by the addition of small amounts of magnesium and titanium, this practice is not wholly satisfactory. Further, the supply of mercury is so limited that the amount required for a large modern plant would represent a major capital investment, even if it did not drive up the market. price. The latter was such a serious problem for the schiller plant, that. General Electric had its purchasing agents all over the world buying small amounts of mercury unobtrusively. The mercury inventory in the 40-Mw Schiller plant is $300,000 \mathrm{lb}$, while that of a 400-Mw p.lant would be about $3 \times 10^{6} \mathrm{lb}$, or about $15 \%$ of the total world production in 1961.9

The health hazard represented by the toxicity of mercury vapor in air is a serious one - so much so that the mercury inventory represents a hazard potential about as great as that associated with the volatile fission products in a reactor for a power plant of the same capacity. That is, it would take about as much air to dilute the mercury vapor to standard tolerance levels as would be required for similar dilution of the volatile fission products accumulated in a nuclear reactor in the course of a year of operation. 
The thermodynamic properties of potassium are well suited for use in a binary vapor cycle in which the steam conditions in the lower temperature portion of the cycle are the same as those used in the more advanced steam plants built in recent years. A potassium-vapor cycle could be used in a stainless steel system to effect a major improvement in cycle efficiency, and when more refractory materials of construction are available at reasonable prices, higher temperatures could be used in the potassium-vapor system to effect further substantial increases in overall cycle efficiency. Experience gained in the course of the ANP and SINAP programs indicates that, in a well-constructed stainless steel system, there should be no troubles with corrosion, mass transfer, or poor wetting of the sort that has plagued the mercury systems for the past 50 years. Thus potassium appears to be a good choice for a modern binarycycle system.

The cost of potassium is much lower than that of mercury - about $\$ 50$ per $\mathrm{ft}^{3}$ as compared with about $\$ 2000$ per $\mathrm{ft}^{3}$ for mercury ${ }^{9}$ - and the volume required per kilowatt is about one-fifth as much for potassium because the good wetting characteristics permit heat fluxes about five times as great. Unlike mercury, potassium is not toxic, but it does burn in air. The ignition temperature is sufficiently low that it sometimes ignites spontaneously at a temperature just above the melting point. It reacts rapidly with water at low pressures, but experiments have shown ${ }^{10}$ that the reaction rate is uniform and not too rapid at temperatures above aboldt, $600^{\circ} \mathrm{F}$. The potassium-water reaction itself is not explosive; however, if the hydrogen evolved mixes with air, the resulting mixture may explode or even detonate. 'lihus, the latter constitutes the principal hazard associated with the potassium-water reaction, and the plant design should be such that the consequences of such a reaction will not be too serious. It should be remembered that a hydrogen explosion is an everyday possibility in plants using hydrogen-cooled generators, whereas it represents a rare contingency in a potassium-vapor plant.

Many attempts have been made to find other materials that would be better than potassium for high-temperature vapor cycles, but only cesium 
and rubidium appear to have the desired characteristics, and both of these are expensive and difficult to procure. An organic compound, fluorocarbon, silicone, or the like may be developed in the future that would be attractive for binary cycles in connection with reactors. As an example, Freon $l 1$ is used as a working fluid for the low-temperature portion of a binary cycle for gas turbines on pipe lines in Texas. To date six or more pumping stations operate unattended with high efficiency and satisfactory reliability. However, thermal decomposition of these organic and similar compounds have proved to be serious at temperatures above $900^{\circ} \mathrm{F}$ with all the fluids tried to date (e.g., Dowtherm).

\section{UEe of Stpereritirel-Pressure Steam Systems}

In view of the long-range nature of the proposed design, it seemed best to employ the most advanced of the steam systems currently in use or proposed, namely, a supercritical-pressure steam system. Table I summarizes data on the 13 supercritical-pressure units that have been built or are under construction in the United States.11-16

Discussions with engineers in the utilities companies that have operated supercritical pressure units indicate that the use of supercritical steam at 4000 to 5000 psi is sound and practicable. There has been some difficulty with copper pickup f'rom Monel tubes in the upper-stage feedwater heaters, but this apparently can be corrected by using steel instead of Monel tubes. Other difficulties experienced have involved air-side' corrosion or erosion or have veen matters of detailed design that have either been corrected or could be corrected in future designs. Air-side corrosion is, of course, an inherent problem in fossil-fueled plants, but i, can be avoided in a nuclear plant.

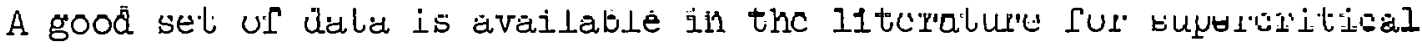
pressure unit No. 2 in the Eddystone plant of the Philadelphia Electric Co. Since the design conditions for unit $\mathbb{N o} .2$ are typical and well suited to the application at hand, the steam conditions of this study were taken to be essentially the same as those of the Eddystone plant. 
Table 1. Summary of Data on United States Supercritical-Pressure Steam Plants

\begin{tabular}{|c|c|c|c|c|c|c|}
\hline Company & Plant Name & $\begin{array}{l}\text { Capacity } \\
(\mathrm{Mw})\end{array}$ & $\begin{array}{c}\text { Throttle } \\
\text { Pressure } \\
\text { (psia) }\end{array}$ & $\begin{array}{l}\text { Steam } \\
\text { Tempera- } \\
\text { ture } \\
\left({ }^{\circ} \mathrm{F}\right)\end{array}$ & $\begin{array}{c}\text { Year of } \\
\text { T.nit.ial } \\
\text { Operation }\end{array}$ & $\begin{array}{l}\text { Refer- } \\
\text { ence }\end{array}$ \\
\hline Obio Power Co. & Philo & 125 & 4500 & 1150 & 1957 & 11,12 \\
\hline $\begin{array}{l}\text { Cleveland Electric } \\
\text { Illuminating }\end{array}$ & Avon & 233 & 3500 & 1100 & 1959 & \\
\hline Philadelphia Electric Co. & $\begin{array}{l}\text { Eddystone No. } 1 \\
\text { Eddystone No. } 2\end{array}$ & $\begin{array}{l}325 \\
325\end{array}$ & $\begin{array}{l}5000 \\
4000\end{array}$ & $\begin{array}{l}1200 \\
1050\end{array}$ & $\begin{array}{l}1960 \\
1960\end{array}$ & $\begin{array}{l}13,14 \\
15\end{array}$ \\
\hline Appalachian Power Co. & Philip Sporn & 450 & 3500 & 1050 & 1960 & 15 \\
\hline Indiana \& Michigan Electric & Breed & 450 & 3500 & 1050 & 1961 & 16 \\
\hline American Electric Co. & Tuwuers Csejk & 580 & 3500 & 1000 & 1963 & 15 \\
\hline Tennessee Valley Authority & Bull Run & 1000 & 3500 & 1000 & 1965 & 15 \\
\hline Public Service Electric & Huds on No. 1 & 400 & 3500 & 1000 & 1965 & 15 \\
\hline Potomac Electric & $\begin{array}{l}\text { Chalk Point No. } 1 \\
\text { Chalk Point No. } 2\end{array}$ & $\begin{array}{l}335 \\
335\end{array}$ & $\begin{array}{l}3500 \\
3500\end{array}$ & $\begin{array}{l}1000 \\
1000\end{array}$ & 1964 & $\begin{array}{l}15 \\
16\end{array}$ \\
\hline Union Electric Co. & $\begin{array}{l}\text { Sioux No. } 1 \\
\text { Sioux No. } 2\end{array}$ & $\begin{array}{l}500 \\
500\end{array}$ & $\begin{array}{l}3500 \\
3500\end{array}$ & $\begin{array}{l}1000 \\
1000\end{array}$ & & $\begin{array}{l}16 \\
16\end{array}$ \\
\hline
\end{tabular}

General Design Considerations

The first step in the design study was to make a thermodynamic analysis of the potassium-vapor cycle coupled to a supercritical-steam cycle similar to that of the second supercritical-pressure unit at the Eddystone plant. The system contemplated is shown in Fig. 2. Since energy is removed efficiently in the potassium-vapor cycle, there is no incentive to increase the peak steam-cycle temperature other than to increase the potassium-vapor density in the condenser and thus reduce the size of the potassium turbine and condenser. Thus, the choice of the temperature level at which heat is interchanged between the condensing potassium and the supercritical-pressure steam depends on balancing the cost of small, very-high-pressure steam equipment against large low-pressure potassiumvapor equipment. Rough estimates indicated that near-minimum costs would be obtained by condensing the potassium at $1100^{\circ} \mathrm{F}$ and transferring the heat to steam at a peak temperature of $1050^{\circ} \mathrm{F}$. The temperature-entropy diagram for the resulting binary vapor cycle is presented in Fig. 3, and the corresponding operating conditions are summarized in Tables 2 and 3. It was possible to employ the steam flow sheet for the Eddystone plant 
UNCLASSIFIEO
ORNL-DWG $64-1235$

S-1, FLEL-TO-SALT HEAT EX ZHAIGER

S-2, SALT-TO-POTASSIUN, BOILEF

B, SLPZRSRITICAL-PRESSURE STEAM GENERATOR

RH-1, REHEATER I

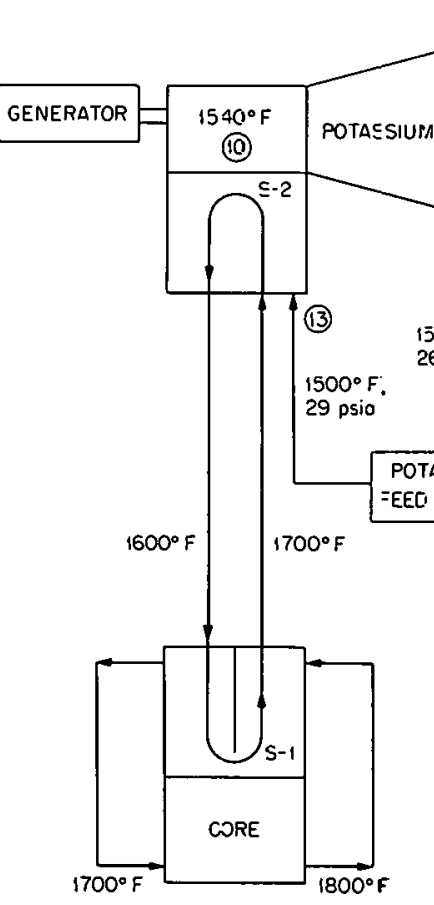

MOLTEN-SÁLT REACTOR

1 (11)

15:

$1100^{\circ} \mathrm{F}$

POTLSSIJM

EEEI HEATER (12)
FUEL NO. 1.32: $\mathrm{LiF}-3 \mathrm{eF} \mathrm{F}_{2}-\mathrm{UF}_{4}-\mathrm{ThF}_{4}(67-18.5-0.5-14$ nole \%)

SAL' NO. K: NJaF-KF-LiF-UF $(10.9-43.5-44.5-1.1$ mole \%

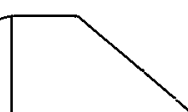

POTASSIUNA-TO-

STEAM BOILER
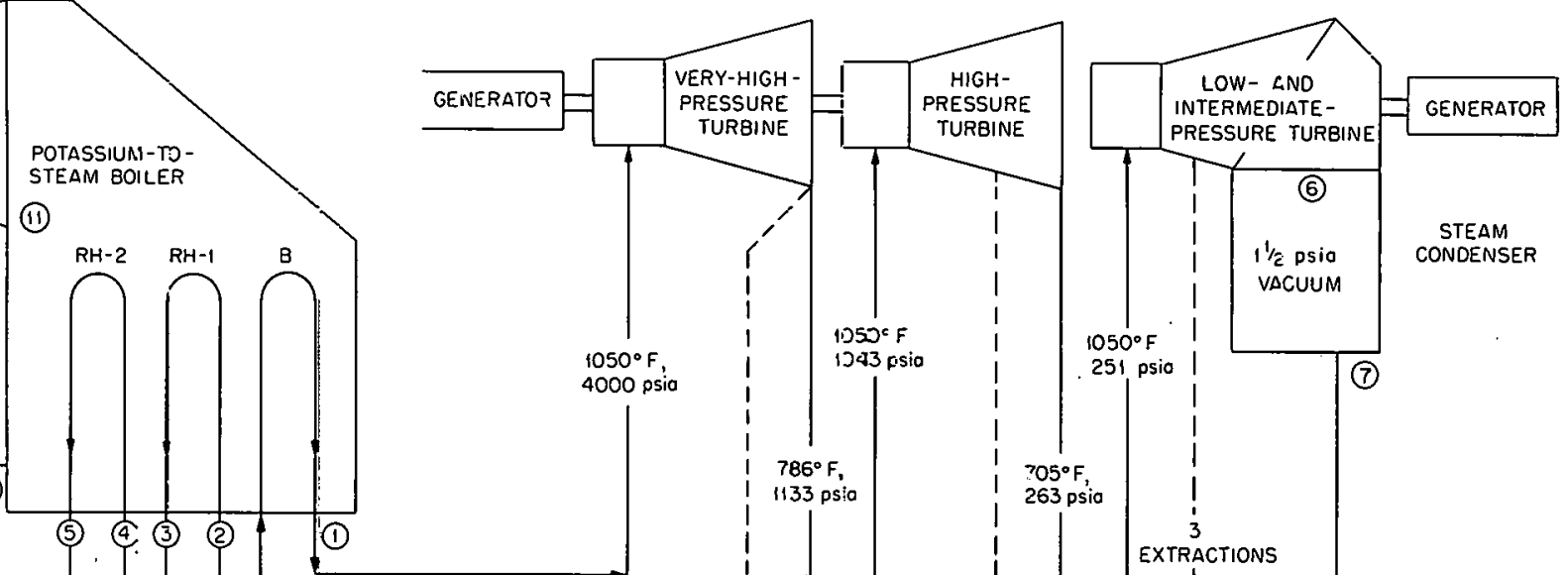

Fig. 2. Flow Diagran for Binary-Vapor-Cycle Fower Plant. 
UNCLASSIFIED

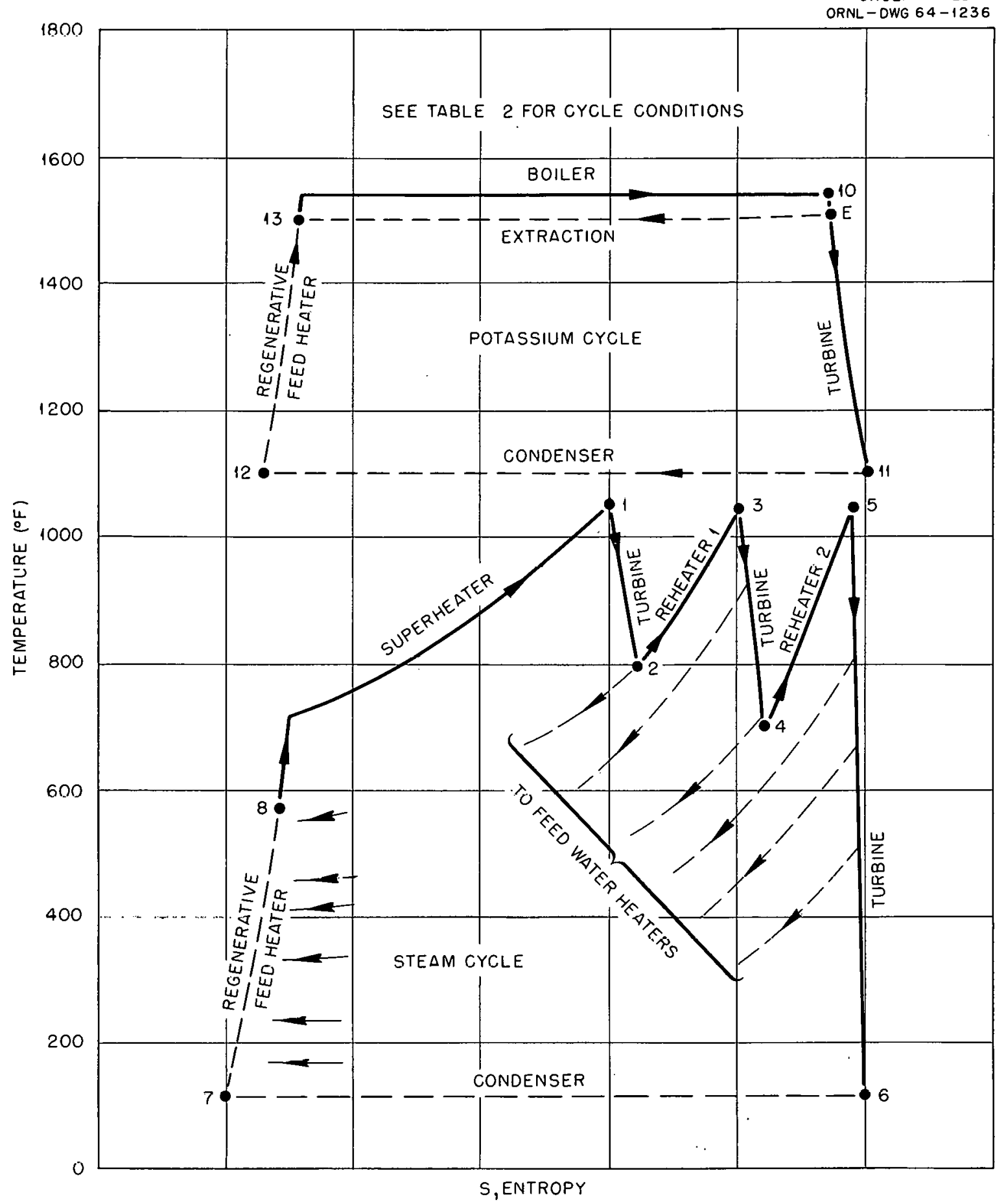

Fig. 3. Temperature-Entropy Diagram for the Steam and Potassium Cycles. 
Table 2. Temperature and Pressure Conditions for the Steam and Potassium Cycles Shown in Fig. 3

\begin{tabular}{lcccc}
\hline & Location & $\begin{array}{c}\text { Pressure } \\
(\text { psia })\end{array}$ & $\begin{array}{c}\text { Temperature } \\
\left({ }^{\circ} \mathrm{F}\right)\end{array}$ & $\begin{array}{c}\text { Enthalpy } \\
(\mathrm{Btu} / \mathrm{lb})\end{array}$ \\
\hline \multirow{2}{*}{ Steam cycle } & 1 & 4000 & 1050 & 1446.1 \\
& 2 & 1133 & 786 & 1374.0 \\
& 3 & 1043 & 1050 & 1535.0 \\
& 4 & 263 & 705 & 1372.7 \\
& 5 & 251 & 1050 & 1552.9 \\
& 6 & 0.50, vacuum & 115 & 1111.6 \\
& 1 & 0.30, vacuum & 1.15 & 52.9 \\
& 8 & 4300 & 558.1 & 560.1 \\
& 10 & 29.0 & 1540 & 1.210 \\
& 11 & 2.4 & 1.1 .00 & 1068 \\
& 12 & 2.4 & 1100 & 290 \\
& 13 & 30.0 & 1500 & 368 \\
\hline
\end{tabular}

Table 3. Temperature and Pressure Conditions for the Steam- and Potassium-Cycle Extractions Shown in Fig. 3

\begin{tabular}{lccc}
\hline & $\begin{array}{c}\text { Pressure } \\
(\text { psia })\end{array}$ & $\begin{array}{c}\text { Temperature- } \\
\left({ }^{\circ} \mathrm{F}\right)\end{array}$ & $\begin{array}{c}\text { Temperature of } \\
\text { Heated Feed } \\
\left({ }^{\circ} \mathrm{F}\right)\end{array}$ \\
\hline Steam cycle extractions & 1136 & 786 & 558 \\
to heat feed & 710 & 938 & 505 \\
& 465 & 823 & 457 \\
& 263 & 705 & 407 \\
& 110 & 830 & 333 \\
& 55 & 667 & 268 \\
Yotassium cycle extraction & 25 & 499 & 164 \\
\hline
\end{tabular}

with essentially no changes. Further, the overall thermal efficiency of the steam portion of the system could be taken as that of the Eddystone plant with allowances for differences between the two systems stemming from such factors as the stack losses and the power requirements for auxiliaries. 
As mentioned, potassium was chosen as the upper-stage working fluid in the proposed binary vapor cycle because its thermodynamic properties make it especially well suited to the application. The pressures are low enough over the desired temperature range so that pressure stresses are not serious, and yet the vapor density is high enough so that system components are not unreasonably large. This can be seen by examining Table 4, which gives the principal physical properties of potassium, 17 along with the corresponding properties of water at the same pressure. These data show that lie specific volumes of potassium liquid and vapor are about the same as the corresponding values for water at the same pressure, and the heat of vaporization is much the same. Other properties, such as the surface tension and the viscosity of the liquid, are within a factor of approximately 2 of being the same. The only major differenre in physical properties between the two fluids is that the thermal conductivity of the liquid potassium is about 60 times that of water. This

Table 4. Comparison of Physical Properties of Potassium and Water for Condensing Conditions

\begin{tabular}{|c|c|c|c|c|}
\hline & \multicolumn{2}{|c|}{ Potassium } & \multicolumn{2}{|c|}{ Water } \\
\hline & Liquid & Vapor & Liquid & Vapor \\
\hline Temperature, ${ }^{\circ} \mathrm{F}$ & 1040.0 & & 115.6 & \\
\hline Pressure, psia & 1.50 & & 1.50 & \\
\hline $\begin{array}{l}\text { Specific volume, } \\
\mathrm{ft}^{3} / \mathrm{lb}\end{array}$ & 0.02269 & 267.15 & 0.01619 & 228.65 \\
\hline Enthalpy, Btu/lb & 283.0 & 1170.4 & 83.56 & 1111. \\
\hline $\begin{array}{l}\text { Heat of vapurLualium, } \\
\text { Btu/Ih }\end{array}$ & $88 \% \cdot 4$ & & 1028.14 & \\
\hline $\begin{array}{l}\text { Specific heat, } \\
\text { Dtu/Il }{ }^{\circ} \mathrm{F}\end{array}$ & 0.1823 & 0.1266 & 0.998 & 0.43 \\
\hline Viscosity, 1b/ft.hr & 0.37 & 0.0189 & 1.42 & 0.029 \\
\hline $\begin{array}{l}\text { Thermal conductivity, } \\
\text { Btu/hr.ft. }{ }^{\circ} \mathrm{F}\end{array}$ & 21.0 & 0.00363 & 0.371 & 0.012 \\
\hline FrandtI No., $c_{p} \mu / k$ & 0.00321 & 0.659 & 3.82 & 1.04 \\
\hline Surface tension, Ib/ft & 0.0041 & & 0.00469 & \\
\hline
\end{tabular}


is advantageous in improving the heat transfer coefficient, especially in the potassium condenser. The much lower specific heat of liquid potassium as compared with that of water is of some advantage in improving the cycle efficiency.

A reactor thermal output of $1000 \mathrm{Mw}$ was taken for the reference design condition with the expectation that the overall thermal efficiency would be close to $54 \%$ and hence would yield a total of about $540 \mathrm{Mw}$ of net electrical output. The flow sheet shown in Fig. 2 was prepared to aid in visualizing the major features of the system.

A number of ovcrall plant layouts was prepared of which that shown in Fig. 4 appeared to be the most promising. With this system, thermal convection is sufficient to remove about $10 \%$ of the reactor power output in the event of failure of the power supply to all the pumps. This is much more than enough to remove the afterheat from fission-product decay.

A wide variety of factors was considered in evolving the series of layouts leading to that presented in $\Gamma i g$. 4. These design precepts are Iisted below:

1. The design should be such that any component of the system may be replaced with little disturbance of other.parts.

2. There should be sufficient shielding between the reactor and the fuel-to-inert-salt heat exchanger and sufficient neutron poison in the latter (to absorb delayed neutrons) to reduce activation of the inert sal.t to a level that would permit limited contact maintenance of any component in the inert salt system, except the fuel-to-inert-salt heat exchanger.

3. Both the fuel pump rotor assemblies and the fuel-to-inert-salt heat exchanger tube bundles should be designed so that they can be iriserted into vertical wells with the seal flange in a shielded zone and contact maintenance dulivilies can bc curried out at the flange, e.g., seal welding and inspection of the flanges.

4. Differential thermal expansion in the piping connecting the hot components should be absorbed either in simple bending of the piping or in toroidal expansion joints. Stainless steel bellows should be used only in low-pressure, low-temperature zones, such as those around penetrations in the containment errvelope. 
UNCLASSIFIED
ORNL-DWG $64-1237$

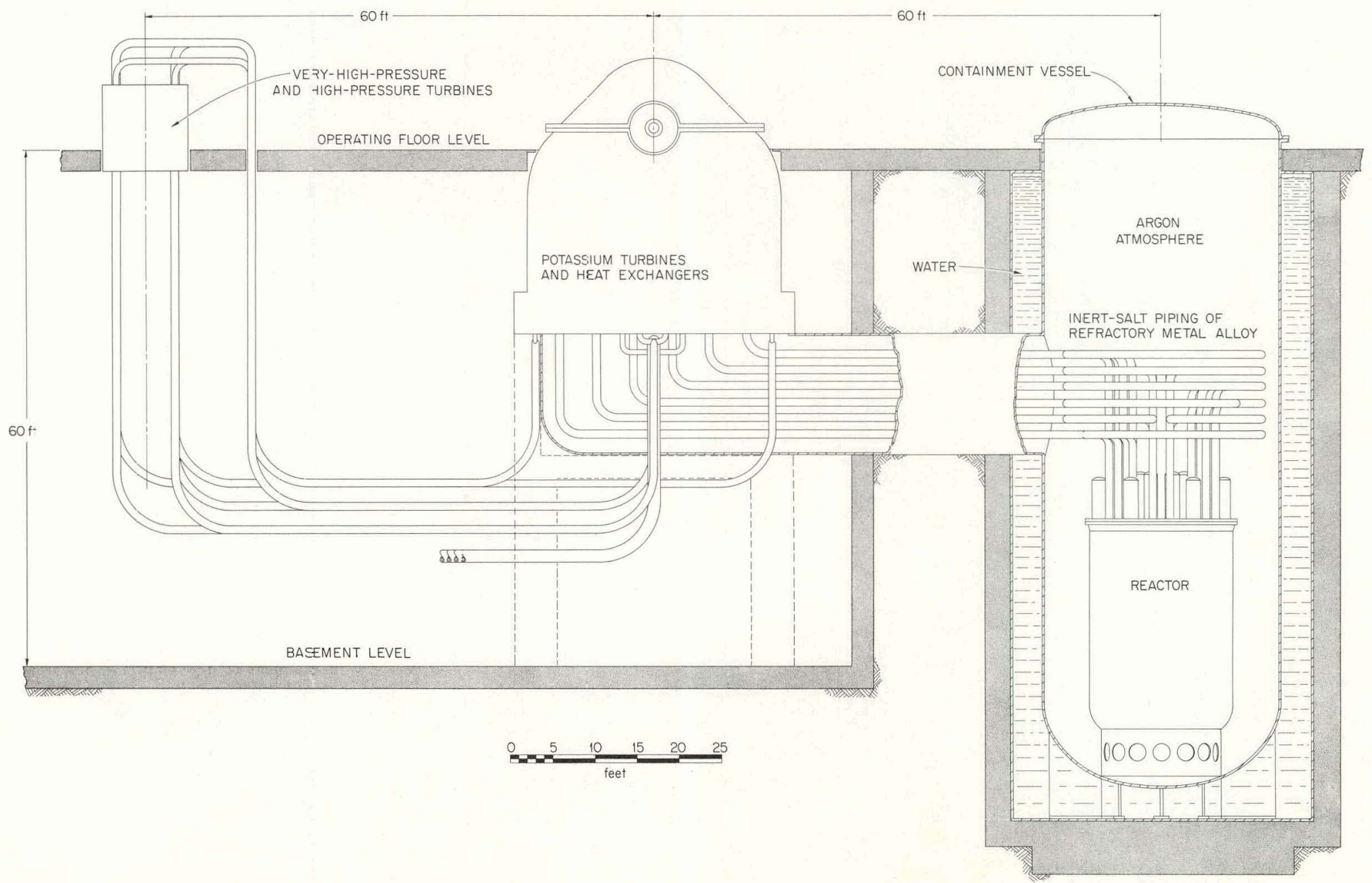

Fig. 4. (a) Typical Elevation Through Binary-Vapor-Cycle Power Plant. 


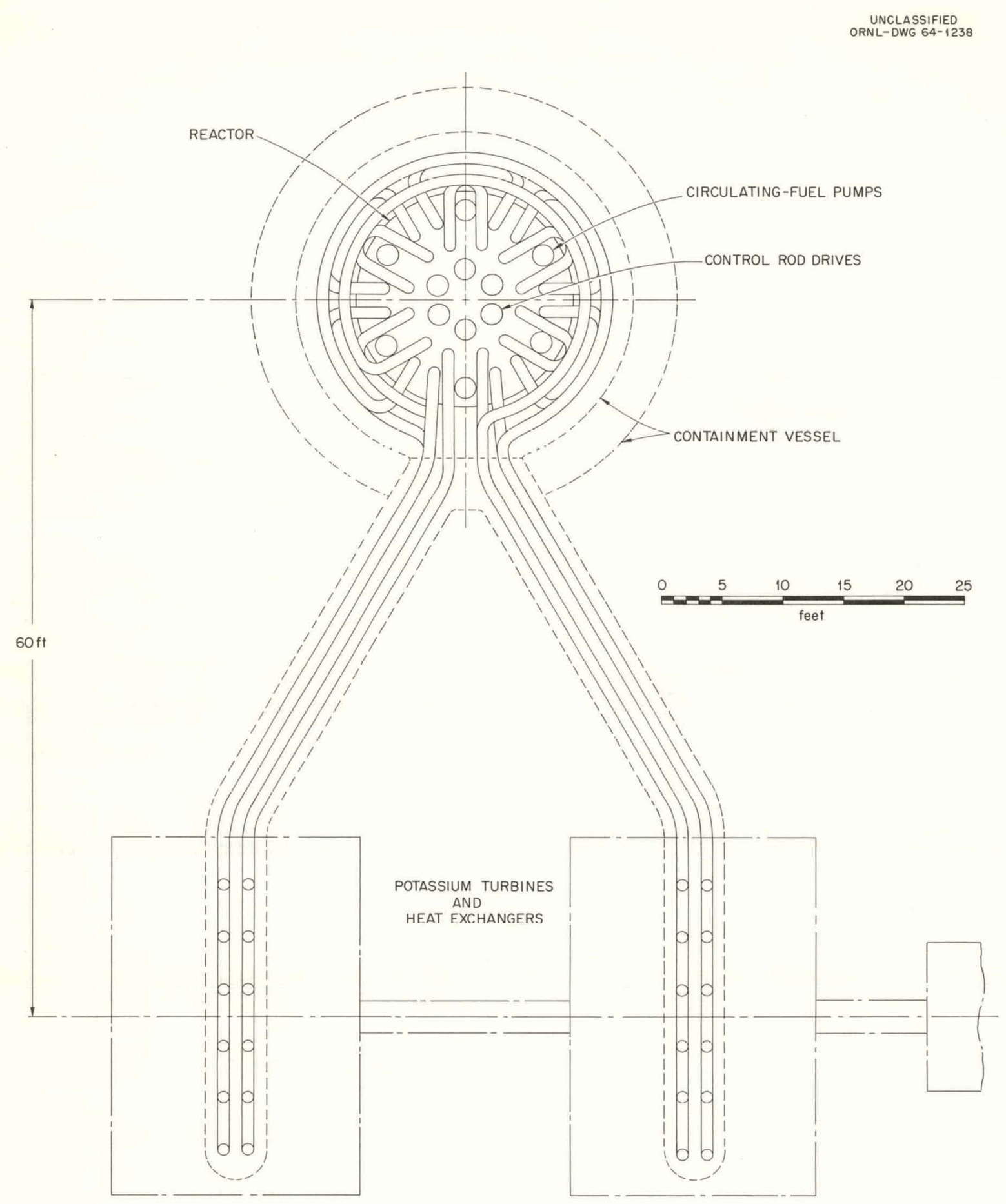

Fig. 4. (b) Plan View of Reactor Area. 
UNCLASSIF ED
ORNL-DWG 64-1239

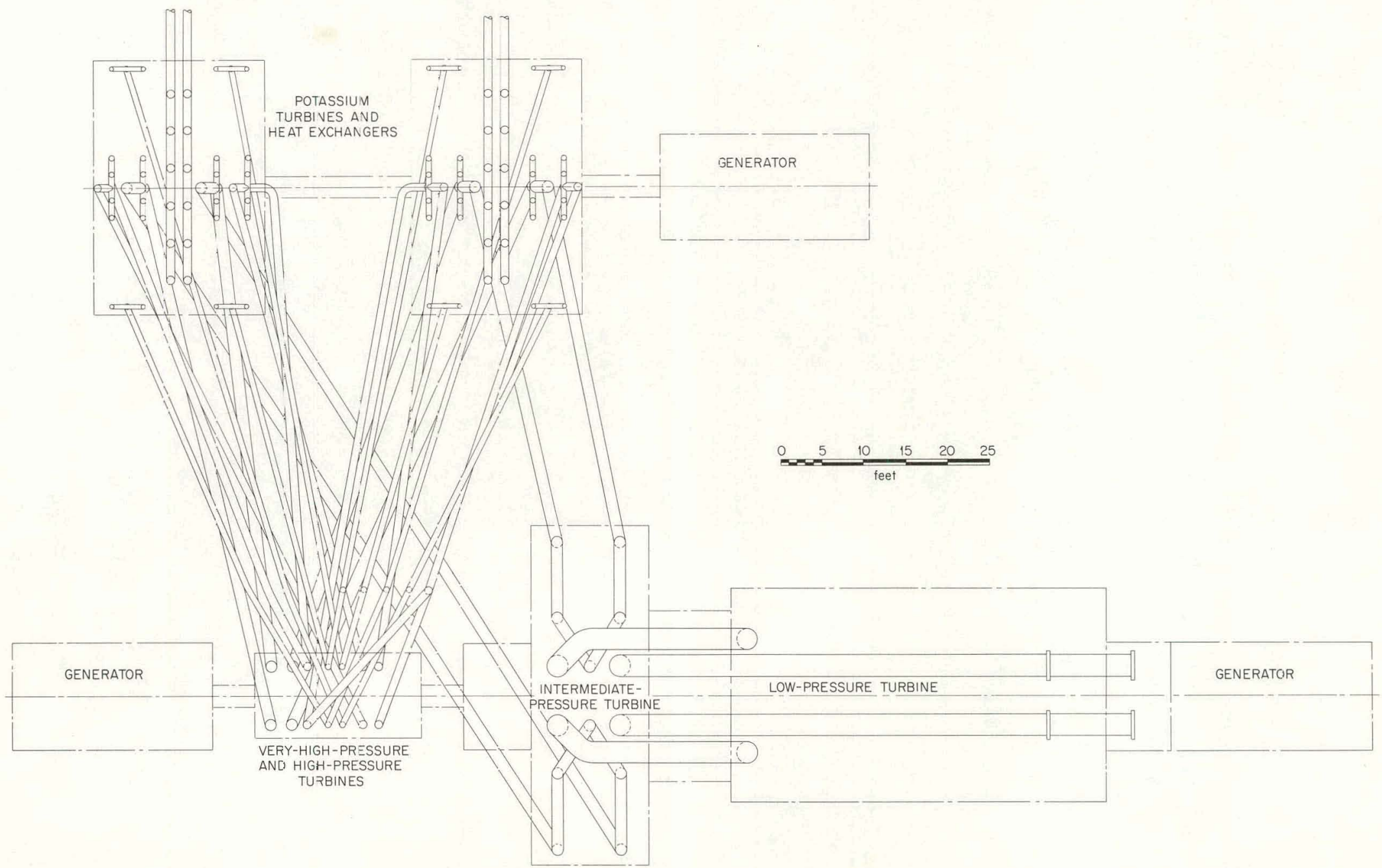

Fig. 4. (c) Plan View of Primary Piping. 
5. All four fluid systems (fuel, inert salt, potassium, and water) should be designed to provide sufficient thermal convection to remove afterheat in the event of complete failure in the power supplied to all the pumps.

6. The inventory of the fuel, inert salt, potassium, and refractory alloy structural material should be kept to a minimum to reduce both the costs and the hazards.

The heat exchanger sizes were based on all refractory alloy tubing: 3/8 in. OD with a 0.040-in.-thick wall. Experience indicates that fouling: of these small-diameter tubes is not a problem in systems where fluid cleanliness requirements are as stringent as they are for the molten-salt and potassium systems. It should be mentioned that the bore of the superheater tubes in the Philo plant of the Ohio Power Company, a supercritical water plant, is 0.40 in.

\section{Component Design}

$\underline{\text { Reactor Core and Heat Exchanger Assembly }}$

As shown in Fig. 5, the reactor core and the fuel-to-inert-salt heat exchanger assembly are mounted in a 17-ft-diam, 26-ft-high, cylindrical shell. The core is $10 \mathrm{ft}$ in diameter and $10 \mathrm{ft}$ in height and is mounted in the lower portion of the shell. It is surrounded with 3 ft of graphite reflector with the 3-ft-long blocks laid with their axes normal to the core-reflector interface so that the heat generated in the graphite reflector can be removed by fuel flowing over either the inboard or outboard ends of the graphite blocks. Fuel in the cracks between the blocks constitutes such a small percentage by volume of the reflector that the fission heat generated in this fuel can also be removed by radial heat conduction through the graphite without a large axial temperature variation along the length of the graphite block.

Fine $\perp$ 'lows axially upward through the core and then up through a central column approximately 7 ft in diameter to the top of the heat exchanger region. Fuel flows downward and then back upward over a baffle between U-tubes in the heat exchanger. It then returns downward in the 


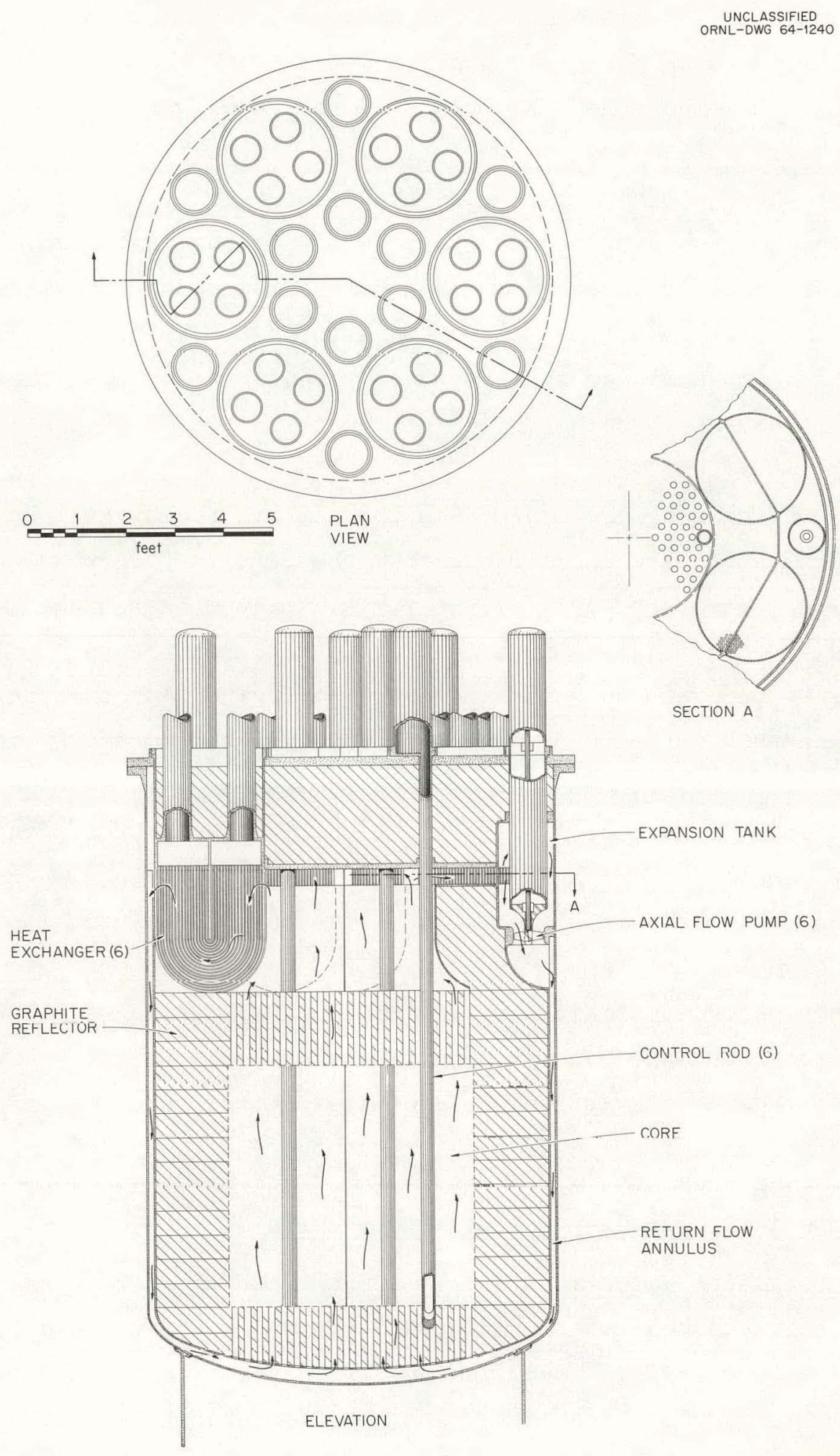

Fig. 5. Molten-Salt Reactor for Binary-Vapor-Cycle Power Plant. 
annular region between the heat exchangers and the outer shell through six axial-flow pumps flange-mounted in wells above the top of the fuel expansion tank. The pumps are driven by long overhung shafts with outboard bearings lubricated by the fuel salt. (A pump with a molten-salt bearing of this type has been operated satisfactorily for 12,000 hr at ORNL.) The heat exchanger consists of six tube bundles, each about 4 ft in diameter and $6 \mathrm{ft}$ in length. The whole arrangement is designed to provide for thermal-convection removal of afterheat. In fact, analysis indicates that it should be so effective in this respect that thermal convection of the fuel should suffice to remove 10 to $20 \%$ of the full-power output.

The control rods are mounted in the central region so that they operate through the fuel-channel riser from the core to the heat exchanger inlet. The control rod drives, the pumps, and the heat exchangers are mounted with their flanges in a relatively cool zone above a 4 -ft-thick shielded region over the heat exchanger and fuel expansion tank. The layout is such that any pump or heat exchanger may be removed by vertical withdrawal from the top without disturbing any other unit. The weight of each unit is such that it more than counterbalances the pressure forces acting at the flange, so only a seal weld is required.

A neutron poison is placed between the top of the graphite reflector over the core and the heat exchanger to reduce activation of the inert salt in the secondary fluid circuit. The cooled fuel stream returning to the core around the outer perimeter of the reflector exerts a modest net radial pressure inward on the graphite blocks, thus tending to force them together and minimize the clearances between them.

Potassium Boiler, Turbine, and Condenser Units

'Ihe potassium-vapor turbines look much like the low-pressure steam turbines for a conventional steam power plant. The tip speed limitations are somewhat higher for the potassium, and hence with an 1800-rpm shaft speed and two turbines (to keep the size of each unit down) the rotor diameter at the outlet end is about $10 \mathrm{ft}$. From five to seven stages are required, with the turbine rotor inlet around $6 \mathrm{ft}$ in diameter. 
The very large volumetric flow rate of the potassium vapor, both out of the boiler to the turbine and out of the turbine into the condenser, made it desirable to incorporate both the potassium boiler and the potassium condenser in units directly beneath the turbine in much the same fashion as is standard practice with conventional steam turbine condensers. To minimize the temperature gradient in the vicinity of the turbine shaft seals and bearings and to keep the temperature of the turbine casing down to $1100^{\circ} \mathrm{F}$ where its strength would not be much lower than at room temperature, the condenser was divided into two sections, with one at either end of the double-flow turbine. The boiler region was placed between these two condenser regions. The general layout is shown in Fig. 6.

As in the heat exchangers incorporated in the reactor pressure vessel, it seemed best to design so that both the potassium boiler and the potassium condenser would consist of a multiplicity of tube bundles, each of which could be installed by moving it into position along a vertical axis and securing it in place with a seal weld. Fortunately, the pressure on the potassium-vapor side is nominal in both cases, i.e., about 15 psi above atmospheric in the potassium boiler and about 12 psi below atmospheric in the potassium condenser. Thus, the pressure loads on the potassium side are small. In fact, the pressure force is of about the same order as the weight of the tube bundle.

A pair of inert-salt pipes delivers salt from each of the fuel-tosalt heat exchanger tube bundles to one of a set of six tube bundles mounted in the potassium boiler casing below each turbine. Each of the potassium boiler tube bundles makes use of about $1000 \mathrm{U}$-shaped tubes. The $\mathrm{U}^{\prime} \mathrm{s}$ are about $5 \mathrm{ft}$ long and inverted so that each tube bundle can be withdrawn vertically downward from a flanged joint at the bottom of the boiler casing. An advantage of this potassium boiler configuration is that it appears to reduce the potassium inventory to a relatively low value for such a large plant, i.e., about $800 \mathrm{ft}^{3}$, or 35,000 $\mathrm{lb}$.

The supercritical-pressure boiler and the reheaters are made up of U-shaped tubes arranged in cylindrical bundles and mounted in a casing under the turbine to serve as the potassium condenser. The feedwater (or reheat steam) enters one leg of a $U$ and flows vertically upward and then returns downward to the tube-bundle outlet. It is to be noted that 


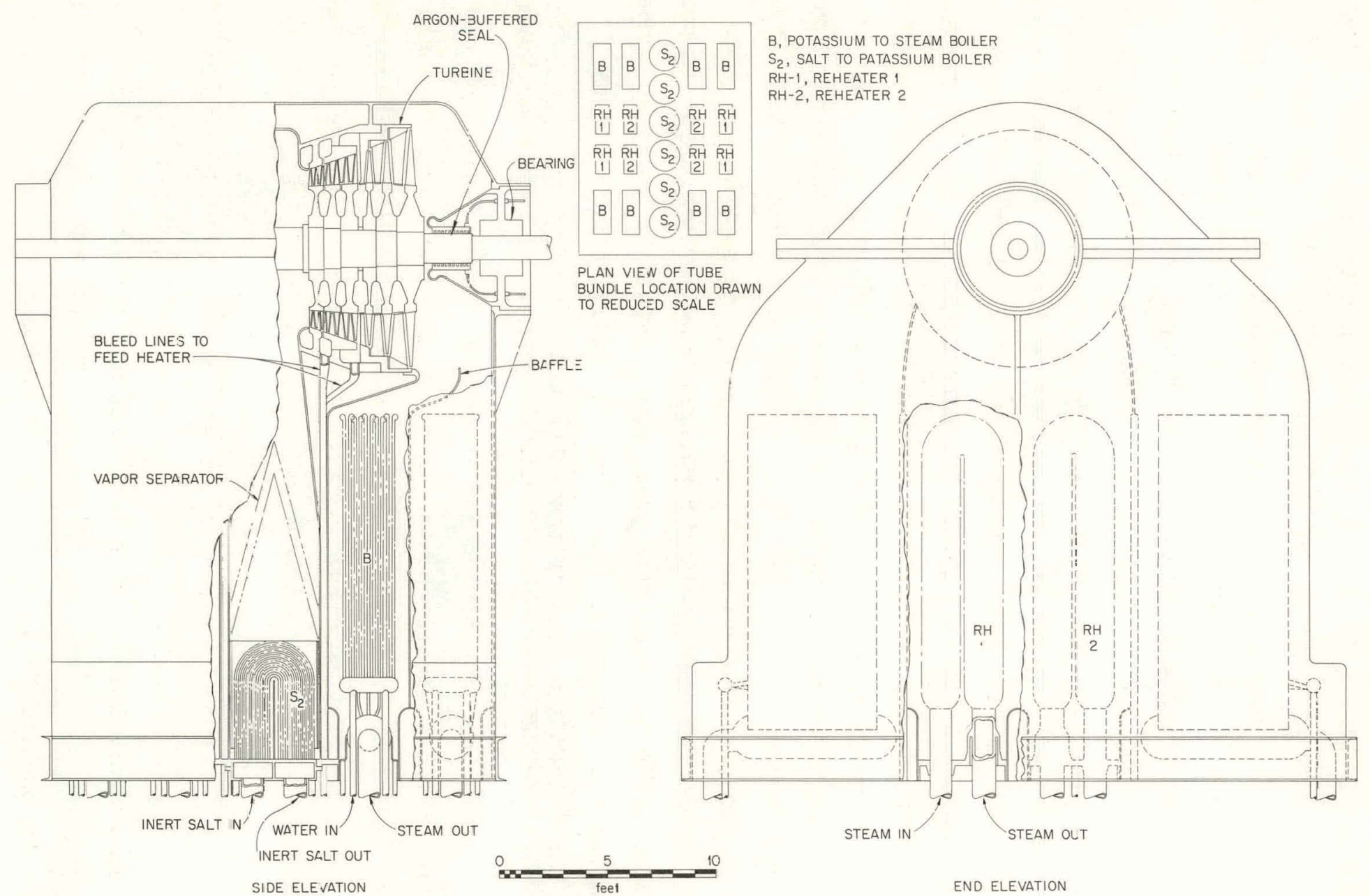

Fig. 6. Potassium Turbine and Heat Exchanger Unit for Binary-VaporCycle Power Plant. 
there is no sharply defined phase change in a supercritical-steam boiler only a steep gradient in the fluid density. This occurs mainly in the first portion of the heated longth of the boilcr tube.

The most difficult set of tube bundles to design was that for the supercritical-water boiler because the high pressures on the water side made it necessary to employ very thick-walled header drums and tubes. While the temperature in the potassium boiler is high, the pressures there are low so that the stress problems are much less severe. The close spacing required of the tubes in the potassium condenser region in order to keep the unit sufficiently compact to fit the turbine led to serious difficulties in laying out the shell and header drum for the superheated steam. Bifurcated tubes similar to those shown in Fig. 7 are employed to reduce the number of penetrations in the superheated-steam header drum and thus reduce the stress concentration problem there. As can be seen in Fig. 6, five rows of nozzles are employed in the steam outlet drum. Each nozzle is connected to a short bifurcated tube, each leg of which is in turn connected to two additional pairs of bifurcated tubes (see Fig. 8) to give two banks of bifurcated tubes. Each of these banks is fitted with a separate feedwater inlet manifold. These are connected to a header that is brought out of the potassium-condenser region by extending it vertically downward through a vertical thermal sleeve.

The reheater tube bundles have the same tube length but only about one-fourth of the tube matrix volume of the supercritical-boiler tube bundles and are located at the in-board ends of the superheater header drums, as indicated in the reduced-scale plan view of Fig. 6. This arrangement was chosen to facilitate access to the connecting piping and the closure welds for the various units. The steam pipes out of the superheater header drums are $10 \mathrm{in.}$ in diameter and are run horizontally just below the closure flange level to reach a region well clear of the congested space beneath the turbine. The much larger pipes for the reheater tube bundles are stiffer and pose more difficult differential thermal expansion problems, and hence they are run vertically downward from the tube bundles in the central region. With this arrangement, any one of the tube bundles can be approached with a specially built machine designed for installing and removing tube bundles with a hydraulic lift. After severing 


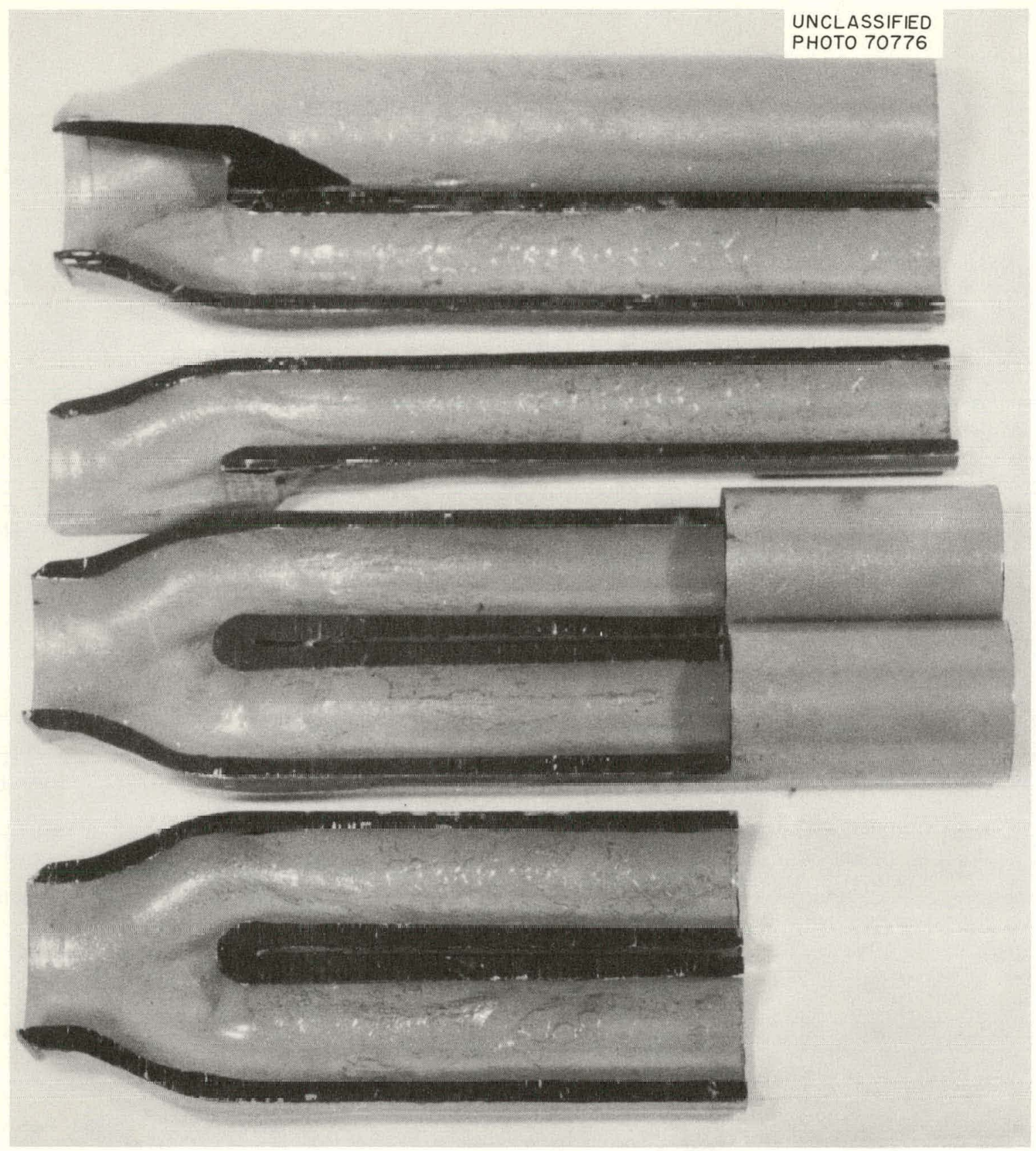

Fig. 7. Scctions Cut Through Four Bifurcated Tubes to Show Their Construction. (Courtesy Combustion Engineering, Inc.)

the connecting piping, attachment points on the tube bundles would be connected to the elevator mechanism on the machine, and the closure weld would be cut with appropriate tooling. The tube bundle would then be lowered and removed from the area, and a new bundle would be installed. 
UNCLASSIFIED

ORNL-DWG 64-1242

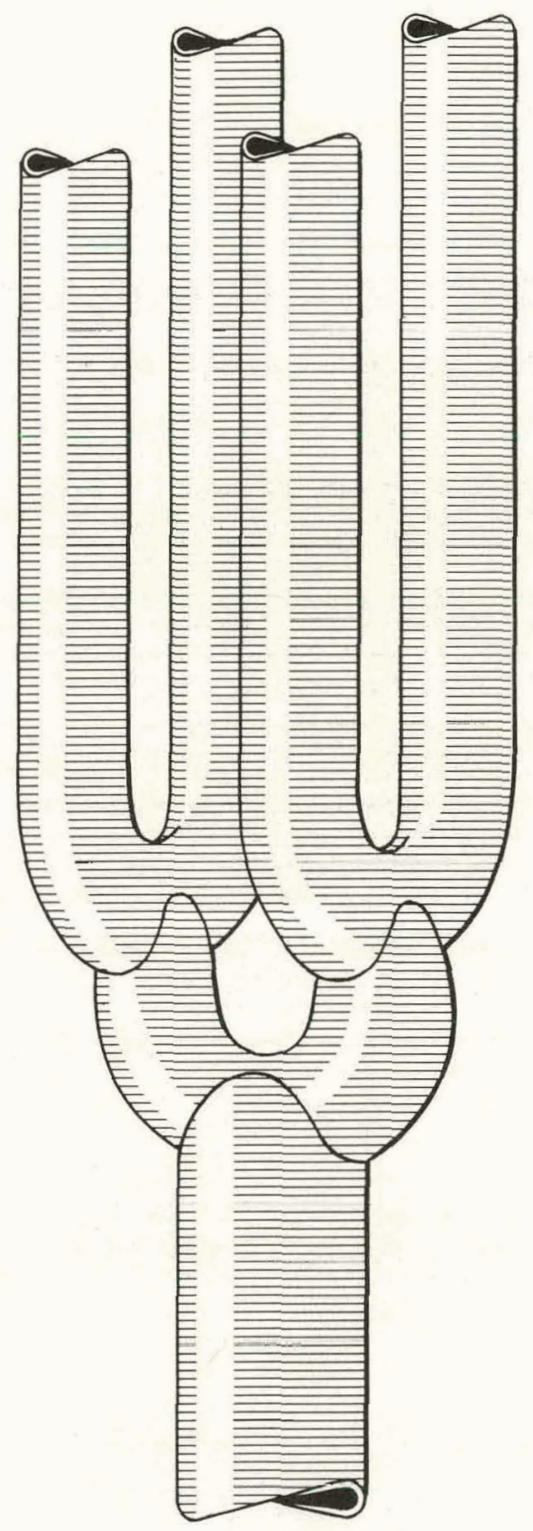

Fig. 8. Detail of Bifurcated Tube Headers for Condenser of BinaryVapor-Cycle Fower Plant.

In the layout shown in Fig. $4 \mathrm{c}$ the columbium pipes carrying the inert salt from the reactor and intermediate heat exchanger assembly up to the potassium-boiler tube bundles are enclosed within a large steel casing so that they can be kept in either a vacuum or an inert gas atmosphere to avoid 
difficulties with oxidation. A bellows joint is required between the casing around these pipes and the stainless steel shell of the potassium boiler. A removable sleeve around these pipes is required to provide space for insertion of the boiler tube bundles. The use of horizontal pipes passing outward from the superheater outlet drums for the supercriticalwater system leaves the floor free for access to these removable sleeves.

A major advantage of the layout of Fig. 6 is that gravitational forces aid in scavenging condensate from the condenser and also help to recirculate the liquid potassium in the potassium boiler. It should be pointed out that the potassium boiler is designed for recirculation with a boiler exit quality of about $10 \%$. A vapor separator in the vapor region above the boiler is designed to remove the liquid potassium and return it to the base of the boiler. The vapor quality supplied to the potassium turbine should be in excess of 99\%. Experience with natural-thermal-convection boiling-potassium systems in the course of the space program indicates that this configuration can be built to work as effectively with potassium as it would with water, and it should give much the same performance characteristics.

Differential expansion in the potassium-vapor turbine casings poses a major problem, particularly since the vapor inlet region operates at about $1540^{\circ} \mathrm{F}$, while the condenser region runs at $1100^{\circ} \mathrm{F}$. The most promising approach seemed to be to make the portion of the turbine casing that supports the stator integral with the potassium boiler and couple this into the bearing housing to give good concentricity in the stator region. The potassium condenser casing was then arranged outside this and connected to it rigidly only at the bearing housing. While this layout presents a number of difficult detailed design problems, it appears that one of the most important, i.e., differential thermal expansion, can be solved with t'lexible omega or bellows joints placed between the boiler and the condenser casings on the one hand and the turbine casing on the other. With the oil-lubricated bearings envisioned, the thermal gradient between the hot portion of the rotor and the $200^{\circ} \mathrm{F}$ bearings must be kept to a reasonable value. A buffer zone about two shaft diameters long will probably be required to give an acceptable thermal gradient in the shaft. This zone can be used for the shaft seal. A reentrant section in the 
housing will be required to accommodate the thermal gradient between the bearing and the large-diameter high-temperature portion of the casing.

\section{Shaft Seals}

The shaft seal configuration of Fig. 6 was chosen, in part, because it seemed to give a good sound design and, in part, because there are two small potassium-vapor turbines under construction that employ essentially similar seals. One of these is at the NASA Lewis Laboratory, and the other is in the GE Gas Turbine Division at Evendale, Ohio. In both instances, the turbine wheel is about a foot in diameter and is separated from oillubricated bearings by a close-clearance seal with an inert buffer gas supplied to the region between the potassium vapor and the oil. Two bleeds are used in each case from the labyrinth, one to carry off a mixture of inert buffer gas and potassium vapor and the other to carry off a mixture of inert gas and oil. Auxiliary equipment is being employed in these systems to separate the potassium from the argon and the oil from the argon, herce the feasibility of conducting these two operations should also be determined in the course of the test programs scheduled for the coming year. In both the GE and the NASA units, argon is employed as the inert gas to reduce the leakage flow rates, which would run approximately three times higher with helium.

Potassium Feed Pumps

While not shown in Fig. 6, two 100-hp potassium feed pumps are 10cated inside the shell of the condenser for each turbine unit. The I-ft-. diam single-stage centrifugal impeller of each pump is coupled directly to a 2-ft-diam single-stage reentry potassium-vapor turbine wheel. The pumps remove the condensate from the base of the potassium condenser and return it through the regenerative feed heaters to the boiler. Since much work is under way in the space power plant program to develop potassium-lubricated bearings, it seems likely that these units can operate with potassium as the lubricant. This arrangement should give a light, compact turbine-driven pump unit that could be installed in the side of the condenser at either end of each large turbine. These should be very reliable, since they would be independent of failures in such components 
as electrical switchgear. Tests have shown that such a turbine-driven pump unit can be "bootstrapped" by simply applying heat to the boiler. A difference in pressure between the boiler and the condenser will begin to develop when the boiler vapor-discharge rate becomes sufficiently high to induce a pressure drop as it flows through the complex passages in the turbine. The liquid level in the condenser will tend to rise a bit above the liquid level in the boiler and, when this difference in level builds up to 6 to $12 \mathrm{in.,} \mathrm{the} \mathrm{vapor} \mathrm{dynamic} \mathrm{forces} \mathrm{acting} \mathrm{on} \mathrm{the} \mathrm{turbine} \mathrm{blades}$ should be sufficient to overcome the friction in the bearings and start the rotor revolving. Once the rotor begins to turn, the centrifugal pump will begin to function, and the pressure in the boiler will rise relative to that in the condenser by an amount much greater than the difference in static head between the condenser hot well and the boiler sump.

Regenerative Feed Heating for the Potassium

Regenerative feed heaters are placed beneath the potassium turbine between the boiler and the condenser. These units are designed to employ vapor bled off between stages of the potassium turbine to preheat the potassium feed to a temperature near the boiling point before supplying it to the potassium boiler: There are a number of reasons for doing this. The most important of these is to avoid thermal stresses in the boiler that would be associated with the admission of liquid feed at a temperature of $440^{\circ} \mathrm{F}$ below the boiler temperature. This problem is so important that it alone may be sufficient to justify the use of a regenerative feed heater. A second reason for using a regenerative feed heating system is that it is possible to obtain a small improvement in overall cycle efficiency, but this improvement is less than 1\%, and by itself is probably not adequate to justify the extra complexity. However, the regenerative feed heater will reduce the size of the potassium boiler from 4 to $8 \%$, depending on the details of the bleed system used for the regenerative feed heater and the proportions employed. Finally, the interstage bleeds in the turbine can be designed to remove moisture and reduce the likelihood of blade erosion. - If the vapor bled off in this fashion is employed for regenerative feed heating, an increase rather than a loss in cycle efficiency can be obtained. 
The regenerator envisioned for this application consists of tube bundles in which the potassium flows upward from the outlet of the feed pump located in the condenser through the tube side to the outlet at the top and then downward into the boiler. Vapor bled off between turbine stages flows downward from the turbine into the shell side of the tube bundles, and the condensate drains into the base of the condenser.

Potassium Storage and Cleanup System

Space is allocated for potassium storage tanks and cleanup equipment. Fortunately, the cost of potassium is only about $\$ 1$ per $1 \mathrm{~b}$, so the investment in potassium is quite small compared with that for the mercury in mercury-vapor plants. For this reason, elaborate cleanup equipment is not justified; if the potassium became badly contaminated, it would be cheaper to dispose of it and buy fresh potassium, since the value of the entire potassium inventory is of the order of only about $\$ 40,000$. However, some potassium cleanup equipment is needed for the removal of oxygen by some process, such as gettering with zirconium, and space is provided for this equipment.

\section{Containment}

A shell is provided to maintain an inert atmosphere (or a vacuum) around the columbium portion of the system to protect it from oxidation, and this shell also serves as a containment envelope for fission products that might escape from the fuel. The arrangement envisioned is shown in Fig. 4c. The cylindrical shell fits fairly closely around the reactor pressure vessel and isolates it from the surrounding concrete shielding. The upper end of this cylindrical containment vessel encloses the equipment employed for removing fission products from the fuel and provides space for maintenance operations for the reactor, control rods, pumps, and heat exchanger tube bundles. Connecting sleeves of elliptical cross section enclose the inert-salt piping to the potassium boilers. Stainless steel bellows are provided between these sleeves and the casing of the potassium boi.ter to provide for misalignment and small amounts of differential thermal expansion. A large-diameter flange is installed in the 
top of the cylindrical shell to facilitate maintenance. The containment shell is to be filled with an inert gas so that oxidation of the refractory metal piping and shells can be kept to a tolerable level. It is possible that it might ultimately prove better to employ a vacuum in this region during operation. In any case, an inert gas could be used during the maintenance operations, and some sort of an elastomer could be used to seal the flanges at the top when coupling to the maintenance equipment.

The building surrounding the complete system, including the potassium and steam turbines, can be designed to be reasonably tight, and blowers discharging through filters can be employed to maintain the building pressure a little below atmospheric so that it will serve as a secondary containment envelope.

\section{Hazards Associated with Fluid Leakage}

The excellent heat removal by thermal convection provided by the layout of Fig. 4, coupled with the multiunit reliability provided by the extensive paralleling of units, eliminates pump stoppage as a major hazard; hence the most obvious hazard is reaction of the potassium with either water or air. In appraising the maximum possible release of energy from this source, it should be noted that the total inventory of potassium in each complete turbine-generator unit will probably be about $400 \mathrm{ft}^{3}$, i.e., about 20,000 $\mathrm{lb}$. The heat that would be released by the combination of all this potassium with water would be about, $40 \times 10^{6}$ Btu. A similar reaction of the potassium with air could yield a slightly larger heat release. In either case the energy release is only about one-third of the fission-product decay heat from the fuel during the first $2 \mathrm{hr}$ after shutdown, and hence the latter presents a greater heat-removal problem in the design of the containment system. The energy available in the superheated water and steam inventory in the steam system totals about $4 \times 10^{6} \mathrm{Btu}$, i.e., only about $10 \%$ of that potentially available from potassium oxidation. It should be noted that the inventory of superheated water and steam in this plant is only about $20 \%$ of that for a conventional coal-fired plant. 
The three principal types of leakage that might lead to the release of chemical energy from reactions of water or air with potassium are a potassium leak from the bottom of the potassium boiler to the atmosphere, a similar leak of air into the potassium condenser, and a steam leak into the potassium condenser. (A leak of molten salt into the potassium or vice versa would not lead to any appreciable chemical reactions.) In any case, the most probable development would be a relatively small leak, so only a small fraction of the total inventory would be released. Past experience with alkali metal fires has indicated that a fire resulting from a potassium leak into a room can be brought under control readily. A steam leak into the potassium condenser would lead to a buildup of pressure within the boiler-turbine-condenser unit as hydrogen was released by the water-potassium reaction. The back pressure of hydrogen in the condenser would build up and reduce the rate at which potassium vapor came over from the boiler. If the salt temperature remained constant, the boiler pressure would increase somewhat and the boiling rate would drop until equilibrium conditions were reached. Continued inflow of steam through the leak would cause the hydrogen pressure to build up further until it blew one of a series of blowout patches designed for this contingency. The hot hydrogen gas emerging from the blowout patches would ignite and burn with air. Pipes extending from the blowout patches to some point above the building would serve to get rid of the hydrogen in the form of a harmless flare. The volume of hydrogen released would be roughly equal to the free volume of the steam leaking from the boiler systeili intu the potassiün system.

There is no way in which a leak in either the steam or the moltensalt system would lead to contamination of the steam system with molten salt or vice versa. Further, there is no way in which the high steam pressure could induce a high pressure in the inert-salt circuit, but even if it did, the short-time yield strength of the tubes in the fuel-to-inertwult heat excliamer would be more than sufficient to withstand the full $4000 \mathrm{psi}$ of the steam system. 
The Maximum Crediblc Accident

While the design of the system for afterheat removal by thermal convection should virtually assure afterheat removal under all conditions, there is still the remote possibility of severe reactor overheating by some mechanism that has not yet been visualized and the escape of fuel into the containment shell. If this were to occur, there should be some means for removing this fission-product decay heat. A simple and relatively inexpensive way of coping with this problem is to employ a water annulus surrounding the lower portion of the reactor containment vessel. In the layout shown in Fig. 4, this annulus has been made $3 \mathrm{ft}$ thick to provide adequate working space between the conlainment shell and the shell holding the water. This gives an adequate supply of water so that even if no makeup water were added, the amount boiled away during the first $24 \mathrm{hr}$ following a maximum credible accident would be only about 10\% of the water available in the reservoir. Any molten salt that drained into the containment shell would form a frozen layer against the shell because heat removal by boiling of the water at the outer surface would exceed the rate at which heat conduction could take place in the frrozen salt. (This was verified in 1954 by experiments conducted in the course of the aircraft reactor progrum.) If a fairly deep puddle of molten fuel. were to collect in the bottom of the contaiment shell, the temperature gradient could become high enough so that the salt would boil at the liquid surface. The vapor rising from the pool would carry both heat and fission products to the cold upper walls of the containment shell and this distribute the heat load over a large area. If uniformly distributed over the walls of the containment shell, the fission products would give a beat flux of only about 10,000 Btu/hr. ft ${ }^{2}$.

\section{Relative Costs}

While the many novel components in the proposed plant make it out, of the question to prepare a definitive cost estimate, some notion of its cost relative to that of a conventional coal-fired plant can be gained from a comparison of the quantities of material required and their unit 
costs. In the first place, the steam system should cost the same as that for a coal-fired plant, except for the steam generator and the piping connecting it to the turbine. The connecting piping for the Eddystone sipercritical unit No. 2 totals approximately $5400 \mathrm{ft}$ and weighs approximately 1,000,000 1b. In the plant layout of Fig. 4, the corresponding piping has a total length of approximately $2000 \mathrm{ft}$ and hence would cost about $40 \%$ as much. Although the writers do not have detailed data for the steel in the boiler tubes for the Eddystone plant, data are available for a somewhat similar boiler, i.e., unit No. 5 of the TVA Colbert plant. This unit ha's a 2400-psi straight-through boiler designed to deliver $500 \mathrm{MW}$ of gross electrical output. The weight of the tubing in this boiler is approximately 5,000,000 lb, while the connecting piping weighs approximately 1,600,000 Ib. The latter value is consistent with the Edrystone Supercritical unit No. 2 if allowance is made for the larger capacity. The stainless steel tubing in the potassium-condenser, water-boiler, superheater, and reheater units in the proposed plant has a total weight of approximately $400,000 \mathrm{lb}$, i.e., about $10 \%$ of the weight of corresponding tubing required for Colbert unit No. 5. Because of the higher pressure, the tubing weight for Eddystone unit No. 2 would probably be considerably greater - a 50\% increase in weight was assumed in preparing Table 5. This drastic reduction in tube weight required for the proposed binary vapor cycle stems partly from the higher heat transfer coefficients and higher heat fluxes available in the potassium condenser, partly from the smaller diameter tubing employed, and partly from the fact that only one side of the tibes in the radiant-heating zolle in a coal-Hired boiler is used for heat transfer purposes. The biggest factor is, of course, the uniform temperature on the potassium side, which means that there is no danger of a hot spot forming and leading to a burn-out condition, and hence the heat exchanger can be designed for a high, fairly uniform heat flux over lite entire surface area.

This high heat flux, coupled with the dusence of a t'low distribution problem, makes it possible to employ an extremely compact heat transfer matrix so that the total volume required for the potassium condenser is somewhat liess than that required for the condenser of a conventional steam turbine of the same output. It should be noted, in particular, that one 
of the principal barriers to heat flow in a steam condenser tube is the relatively low-thermal-conductivity film of condensate. The high thermal conductivity of the liquid potassium essentially eliminates this barrier to heat transfer. However, the biggest factor in reducing the size of the potassium condenser in the proposed design, as compared with a conventional steam condenser, is the $150^{\circ} \mathrm{F}$ mean temperature difference between the condensing vapor and the fluid being heated, i.e., over five times the value ordinarily used in conventional steam plants.

The columbium tubing required for both the fuel-to-inert-salt heat exchanger and the inert-salt-to-potassium boiler has a total weight somewhat less than 100,000 1b. ORNL metallurgists estimate that by 1980 the cost per foot of this tubing will be roughly 20 times that of stainless steel tubing for the same tube diameter and wall thickness. Even on this basis, however, the cost of the columbium tubing for the proposed plant should be about the same as the cost of the steel tubing for a conventional coal-fired plant such as unit No. 5 of the IVA Colbert plant.

The columbium piping between the fuel-to-inert-salt heat exchanger and the salt-to-potassium boiler would weigh about 30,000 1b. This would be equivalent in cost to approximately 600,000 lb of stainless steel piping. Since the wall thickness of this piping need be only $1 / 4$ to $1 / 2$ in., its cost coupled with the cost of the steam piping in the proposed plant would still be less than that of the corresponding steam piping for a coal-fired plant of equivalent capacity.

An important area in which the cost of the binary-vapor-cycle plant proposed should be much less than that for a conventional coal-fired steam plant is in the size of the bullding. The furnace for a conventional coal-fired plant commonly runs $120 \mathrm{ft}$ high and requires substantial amounts of space, both above and beneath it, and a large floor area. The saving in the steel required for the building, coal storage bins, ash hoppers, etc., should much more than compensate for the steel required in the containment shell around the reactor, and thus the overall building cost should be less for the nuclear plant. 


\section{Calculation of Cycle Efficiencies}

The total cycle efficiency of the power plant, $\eta$, was determined by combining the cycle efficiencies for the potassium and steam cycles, as follows :

$$
\eta=\eta_{k}+\left(1-\eta_{k}\right) \eta_{s}
$$

where $\eta_{k}$ and $\eta_{s}$ are the cycle efficiencies for the potassium and steam cycles, respectively. Figure 3 shows the temperature-entropy diagram both for the potassium and steam cycles. In the high-temperature cycle, potassium is evaporated at $29 \mathrm{psia}\left(1540^{\circ} \mathrm{F}\right)$ to give saturated vapor and then expanded through the potassium turbine to 2.4 psia ( $1100^{\circ} \mathrm{F}$ ) with a turbine efficiency of $75 \%$. To simplify the calculations, one-stage extraction at $26 \mathrm{psia}$ and $1510^{\circ} \mathrm{F}$ was assumed for regeneratively heating the liquid potassium feed to $1500^{\circ} \mathrm{F}$. This is simply a rough approximation. It is optimistic in that it assumes a $10^{\circ} \mathrm{F}$ approach temperature at the hot end of the feed heater. However, this effect is more than offset by the fact that use of a single extraction point gives a pessimistic estimate of the cycle efficiency, since four or five extraction points would be used in the actual plant, and this would increase the thermodynamic cycle efficiency. The data used for the pressures, temperatures, and enthalpies for the potassium vapor cycle for the various locations shown in Fig. 3 are listed in Table 6.

The fraction $F$ of potassium to be extracted from the turbine to heat the feed potassium to a $1500^{\circ} \mathrm{F}$ liquid was calculated from:

$$
F\left(H_{E}-H_{13}\right)=(I-F)\left(H_{13}-H_{12}\right)
$$

or

$$
\mathrm{F}=\frac{\mathrm{H}_{13}-\mathrm{H}_{12}}{\mathrm{H}_{\mathrm{E}}-\mathrm{H}_{12}}=\frac{368-290}{1195-290}=0.0865 .
$$

The cycle efficiency for the potassium cycle was evaluated from the following relation: 
Table 6. Pressures; Temperatures, and Enthalpies for the Potassium Vapor Cycle

\begin{tabular}{|c|c|c|c|}
\hline Location & $\begin{array}{l}\text { Pressure } \\
\text { (psia) }\end{array}$ & $\begin{array}{l}\text { Temperature } \\
\left({ }^{\circ} \mathrm{F}\right)\end{array}$ & $\begin{array}{c}\text { Enthalpy, } \mathrm{H} \\
(\mathrm{Btu} / \mathrm{lb})\end{array}$ \\
\hline 10 & 29.0 & 1540 & 1210 \\
\hline E-Extraction & 26.0 & 1500 & 1195 \\
\hline \multicolumn{4}{|l|}{11} \\
\hline $\begin{array}{l}\text { If isentropic } \\
\text { Actual }\left(\eta_{k}=0.75\right)\end{array}$ & $\begin{array}{l}2.4 \\
2.4\end{array}$ & $\begin{array}{l}1100 \\
1100\end{array}$ & $\begin{array}{l}1021 \\
1068\end{array}$ \\
\hline 12 & 2.4 & 1100 & 290 \\
\hline 13 & 26.0 & 1500 & 368 \\
\hline
\end{tabular}

$$
\begin{aligned}
\eta_{k}= & \frac{\text { Net work done in potassium turbine }}{\text { Total heat input to the cycle }} \\
= & \frac{\left(\mathrm{H}_{10}-\mathrm{H}_{\mathrm{E}}\right)+(1-\mathrm{F})\left(\mathrm{H}_{\mathrm{E}}-\mathrm{H}_{11}\right)}{\mathrm{H}_{10}-\mathrm{H}_{13}} .
\end{aligned}
$$

Substituting numerical values in Eq. (3) gives

$$
\eta_{k}=\frac{(1210-1195)+(1-0.0865)(1195-1068)}{1210-368}=0.156 .
$$

The steam-cycle portion of the power plant was assumed to be the same as that nf Eddystone Supcreritical unll INo. 2. F'or this system, with 4000-psia, $1050^{\circ} \mathrm{F}$ steam with two stages of rcheat to $1050^{\circ} \mathrm{F}$, and a $11 / 2-$ psi vacuum, the cycle efficiency was $40.7 \% .^{1}$ This figure is for the net efficiency, including allowances for the boiler feed pumps, the boilerefficiency and stack losses, and auxiliaries other than the boiler feed pumps. For the reactor power plant, eliminating the boiler-efficiency and stark losses and allowing $I \%$ for like fuel and inert-salt circulating pumps gave a net steam-cycle efficiency of $46.2 \%$. The total cycle efficiency for the power plant was evaluated by combining the potassium- and steam-cycle efficiencies according to the relation given by Eq. (1), which gives: 


$$
\eta=0.156+(1-0.156) \times 0.462=0.546
$$

Thus, the net overall cycle efficiency is about 54\%. A lower steam condenser temperature would improve the cycle efficiency one or two points.

\section{Sizing of Heat Exchangers}

A summary of the calculations for sizing the heat exchangers is presented in Table 7. The basic assumptions made and the calculational procedure adopted in obtaining the results presented in this table are given below.

\section{Heat Exchanger's}

There are four principal heat exchangers in the present plant layout.

1. The fuel No. 133-to-salt No. 12 axial-flow heat exchanger has salt No. 12 flowing inside the tubes in the opposite direction to the fuel. In this unit, relatively small tubes, 3/8 in. OD with 0.040-in.thick walls, are used to reduce the heat exchanger size and thereby reduce the inventories of both the columbium and the fuel in the system. U-shaped tubes are employed to provide for thermal expansion and to reduce the height of the heat exchanger matrix. The spacing between the tubes was determined from pressure-drup consideration.

2. The salt No. 12-to-potassium boiler is of 3/8-in. -OD, 0.0/0-in.wall columbium tubes, with potassium boiling at $1540^{\circ} \mathrm{F}$ outside of the tubes. A U-tube arrangement is used for the bundles.

3. The potassium-to-steam boiler is of 3/4-in.-OD, 3/8-in.-ID stainless steel tubes, with potassium condensing at $1100^{\circ} \mathrm{F}$ outside the U-tube bundles and generating supercritical steam at 4000 psia and $1050^{\circ} \mathrm{F}$ inside the tubes.

4. The steam reheaters are made of 1.0-in. -OD, 0.8-in.-ID stainless steel. tubes for 1090-psia reheat and of 1.0-in. -OD, 0.875-in. -1D stainless steel tubes for 257-psia reheat. As in the boiler, heat is supplied by potassium condensing at $1100^{\circ} \mathrm{F}$, and a U-tube arrangement is used.

Data on these units are presented in Table 7. 
Table 7. Summary of Flow Rates, Flow Areas, Tube Lengths, and Weights for the Heat Exchangers in a 1000-Mw (thermal) Binary-Vapor-Cycle Power Plant

\begin{tabular}{|c|c|c|c|c|c|}
\hline & $\begin{array}{l}\quad \text { Fuel No. } \\
\text { 133-to-Salt } \\
\text { No. } 12 \text { Heat } \\
\text { Exchangerb }\end{array}$ & $\begin{array}{l}\text { Salt No. 12- } \\
\text { to-Potassium } \\
\text { Heat } \\
\text { Exchanger }\end{array}$ & $\begin{array}{l}\text { Potassium- } \\
\text { to-Steam } \\
\text { Boiler }\end{array}$ & Reheater 1 & Reheater 2 \\
\hline Tube material & Columbium & Columbium & $\begin{array}{l}\text { Stainless } \\
\text { steel }\end{array}$ & $\begin{array}{l}\text { Stainless } \\
\text { steel }\end{array}$ & $\begin{array}{l}\text { Stainless } \\
\text { steel }\end{array}$ \\
\hline Tube size, in. & $\begin{array}{l}3 / 8 \text { OD } \\
0.040 \text { wall }\end{array}$ & $\begin{array}{l}3 / 8 \text { OD } \\
0.040 \text { wall }\end{array}$ & $\begin{array}{l}3 / 4 \text { OD } \\
3 / 8 \text { ID }\end{array}$ & $\begin{array}{l}1.0 \mathrm{OD} \\
0.8 \mathrm{ID}\end{array}$ & $\begin{array}{l}1.0 \mathrm{OD} \\
0.875 \mathrm{ID}\end{array}$ \\
\hline \multicolumn{6}{|l|}{ Fluias } \\
\hline $\begin{array}{l}\text { Tube side } \\
\text { Shell side }\end{array}$ & $\begin{array}{ll}\text { Salt No. } 12 \\
\text { Fuel No. } 133\end{array}$ & $\begin{array}{l}\text { Salt No. } 12 \\
\text { Boiling } \\
\text { potassium }\end{array}$ & $\begin{array}{l}\text { Steam } \\
\text { Condensing } \\
\text { potassium }\end{array}$ & $\begin{array}{l}\text { Steam } \\
\text { Condensing } \\
\text { potassium }\end{array}$ & $\begin{array}{l}\text { Steam } \\
\text { Condensing } \\
\text { potassium }\end{array}$ \\
\hline \multicolumn{6}{|l|}{ Inlet temperature, ${ }^{\circ} \mathrm{F}$} \\
\hline $\begin{array}{l}\text { Tube side } \\
\text { Shell side }\end{array}$ & $\begin{array}{l}1600 \\
1800\end{array}$ & $\begin{array}{l}1700 \\
1500\end{array}$ & $\begin{array}{l}558 \\
1100\end{array}$ & $\begin{array}{l}786 \\
1100\end{array}$ & $\begin{array}{l}705 \\
1100\end{array}$ \\
\hline \multicolumn{6}{|l|}{ Outlet temperature, ${ }^{\circ} \mathrm{F}$} \\
\hline $\begin{array}{l}\text { Tube side } \\
\text { Shell side }\end{array}$ & $\begin{array}{l}170 n \\
1700\end{array}$ & $\begin{array}{l}1600 \\
1540\end{array}$ & $\begin{array}{l}1050 \\
1100\end{array}$ & $\begin{array}{l}1050 \\
1100\end{array}$ & $\begin{array}{l}1050 \\
1.100\end{array}$ \\
\hline $\begin{array}{l}\text { Mean temperature differ- } \\
\text { ence, }{ }^{\circ} \mathrm{F}\end{array}$ & 100 & 118 & $166, c 460^{d}$ & 145 & 165 \\
\hline \multicolumn{6}{|l|}{ Mean pressure, psia } \\
\hline $\begin{array}{l}\text { Tube side } \\
\text { Shell side }\end{array}$ & $\begin{array}{l}70 \\
70\end{array}$ & $\begin{array}{l}70 \\
29\end{array}$ & $\begin{array}{l}4000 \\
2.4\end{array}$ & $\begin{array}{l}1090 \\
2.4\end{array}$ & $\begin{array}{l}257 \\
2.4\end{array}$ \\
\hline $\begin{array}{l}\text { Pressure drop for tube matrix, } \\
\text { psia }\end{array}$ & & & & & \\
\hline $\begin{array}{l}\text { Tube side } \\
\text { Shell side }\end{array}$ & $\begin{array}{l}10 \\
23\end{array}$ & $\begin{array}{l}24 \\
1\end{array}$ & $\begin{array}{l}50 \\
0.05\end{array}$ & 5 & 8 \\
\hline \multicolumn{6}{|l|}{ Fluid density, $1 b / \mathrm{ft}^{3}$} \\
\hline $\begin{array}{l}\text { Tube side } \\
\text { Shell side }\end{array}$ & $\begin{array}{l}117 \\
218\end{array}$ & $\begin{array}{l}117 \\
0.056^{\mathrm{e}}\end{array}$ & $\begin{array}{l}5.36^{\mathrm{e}} \\
0.0055^{f}\end{array}$ & $\begin{array}{l}1.28^{\mathrm{e}} \\
0.0055^{\mathrm{f}}\end{array}$ & $\begin{array}{l}0.29 \mathrm{e} \\
0.0055^{f}\end{array}$ \\
\hline \multicolumn{6}{|l|}{ Total flow rate, $1 \mathrm{~b} / \mathrm{sec}$} \\
\hline $\begin{array}{l}\text { Tube side } \\
\text { Shell side }\end{array}$ & $\begin{array}{l}21,000 \\
28,700\end{array}$ & $\begin{array}{l}21,000 \\
1,115\end{array}$ & $\begin{array}{l}746 \\
751\end{array}$ & $\begin{array}{l}630 \\
115\end{array}$ & $\begin{array}{l}508 \\
104\end{array}$ \\
\hline \multicolumn{6}{|l|}{ Mass flow rate, $1 \mathrm{~h} / \mathrm{ft}^{2}$. sec } \\
\hline $\begin{array}{l}\text { Thihe side } \\
\text { Shell side }\end{array}$ & $\begin{array}{l}3 x_{-10} \\
1620\end{array}$ & $\begin{array}{l}20000 \\
7.6\end{array}$ & $\begin{array}{l}10 \\
1.65\end{array}$ & $\begin{array}{l}1000 \\
1.65\end{array}$ & $\begin{array}{l}70 \\
1.65\end{array}$ \\
\hline \multicolumn{6}{|l|}{ Total flow passage area, $\mathrm{ft}^{2}$} \\
\hline $\begin{array}{l}\text { Tube side } \\
\text { Shell side }\end{array}$ & $\begin{array}{l}20.2 \\
17.7\end{array}$ & $\begin{array}{l}11.5 \\
147.0\end{array}$ & $\begin{array}{l}10.5 \\
460.0\end{array}$ & $\begin{array}{l}6.3 \\
70.0\end{array}$ & $\begin{array}{l}7.4 \\
64.0\end{array}$ \\
\hline $\begin{array}{l}\text { a Based on combined cycle ef } \\
0.156 \text { and steam cycle efficienc. } \\
{ }_{\text {bounterflow, axial. }} \\
c_{\text {Sinnerheater. }} \\
{ }_{\text {Ecunumlzer. }} \\
e_{\text {At outlet. }} \\
f_{\text {At inlet. }}\end{array}$ & $\begin{array}{l}\text { fficiency of } \\
y \text { of } 0.462 .\end{array}$ & 54, i.e., po & ssium cycle & ficiency of & , \\
\hline
\end{tabular}


Table 7 (continued)

\begin{tabular}{|c|c|c|c|c|c|}
\hline & $\begin{array}{l}\text { Fuel No. } \\
\text { 133-to-Salt } \\
\text { No. } 12 \text { Heat } \\
\text { Exchangerb }\end{array}$ & $\begin{array}{l}\text { Salt No. 12- } \\
\text { to-Potassium } \\
\text { Heat } \\
\text { Exchanger }\end{array}$ & $\begin{array}{l}\text { Potassium- } \\
\text { to-steam } \\
\text { Boiler }\end{array}$ & Reheater 1 & Reheater 2 \\
\hline \multicolumn{6}{|l|}{ Velocity, ft/sec } \\
\hline $\begin{array}{l}\text { Tube side } \\
\text { Shell side }\end{array}$ & $\begin{array}{l}7.4 \\
7.4\end{array}$ & $\begin{array}{l}13.1 \\
136.0^{\mathrm{e}}\end{array}$ & $\begin{array}{l}13.5^{\mathrm{e}} \\
315 . \mathrm{O}^{\mathrm{f}}\end{array}$ & $\begin{array}{l}72.0^{\mathrm{e}} \\
275.0^{\mathrm{f}}\end{array}$ & $\begin{array}{l}200^{e} \\
250^{f}\end{array}$ \\
\hline $\begin{array}{l}\text { Flow area per tube, } \mathrm{ft}^{2} \\
\text { Tube side } \\
\text { Shell side }\end{array}$ & $\begin{array}{l}0.475 \times 10^{-3} \\
0.415 \times 10^{-3}\end{array}$ & $0.475 \times 10^{-3}$ & $0.769 \times 10^{-3}$ & $3.5 \times 10^{-3}$ & $4.18 \times 10^{-3}$ \\
\hline $\begin{array}{l}\text { Fluid volume in matrix, } \mathrm{ft}^{3} \\
\text { Tube side } \\
\text { Shell side }\end{array}$ & $\begin{array}{l}170 \\
196\end{array}$ & $\begin{array}{l}80.5 \\
975\end{array}$ & 235 & 24.5 & 23.9 \\
\hline Thube length, ft & 9.6 & 7.0 & 22.6 & 22.9 & 2.3 .2 \\
\hline Total number of tubes & 42,500 & 24,200 & 13,800 & 1.800 & 1750 \\
\hline Total tube length, ft & 408,000 & 169,000 & 312,000 & 41,000 & $40 ; 500$ \\
\hline Total tube weight, Ib & 65,200 & 27,100 & 364,000 & 38,300 & 25,800 \\
\hline Total surface area, $\mathrm{ft}^{2}$ & 40,000 & 16,600 & 61,000 & 107,000 & 106,000 \\
\hline $\begin{array}{l}\text { Total cross section with } \\
\text { U-bundle arrangement, } \text { ft }^{2}\end{array}$ & 100 & 175 & 570 & 86 & 80 \\
\hline Number of units & 6 & 12 & 16 & 8 & 8 \\
\hline $\begin{array}{l}\text { Diamctcr of equivalent } \\
\text { circular unit, ft }\end{array}$ & 4.6 & 4.3 & 0.7 & 3.7 & 3.6 \\
\hline Number of $U$ tubes per unit & 7080 & 2020 & 880 & 222 & $2 ? ?$ \\
\hline
\end{tabular}

\section{Flow Rates}

The first step in the calculations was the estimation of the tolal mass flow rates of the fluids in the heat exchangers listed above. These were determined by equating the total heat rate, $Q$, to the heat carried by the fluid, that is,

$$
Q=W c_{p} \delta t
$$

where $W$ is the fluid flow rate, $c_{p}$ is the fluid specific heat, and $\delta t$ is the temperature drop. A 1000-Mw heat generation rate in the reactor is equivalent to $0.946 \times 10^{6} \mathrm{Btu} / \mathrm{sec}$. Therefore, from Eq. (4) the flow rate of fuel No. 133 was found to be $28,700 \mathrm{lb} / \mathrm{sec}$, assuming a specific heat of $0.33 \mathrm{Btu} / \mathrm{Ib} \cdot{ }^{\circ} \mathrm{F}$ and a temperature drop of $100^{\circ} \mathrm{F}$. Similarly the flow rate for salt No. 12 was $21,000 \mathrm{Ib} / \mathrm{sec}$ for a specific heat of 0.45 $\mathrm{Btu} / \mathrm{lb} \cdot{ }^{\circ} \mathrm{F}$ and a temperature rise of $100^{\circ} \mathrm{F}$. Similarly, a flow rate of 
$1115 \mathrm{Ib} / \mathrm{sec}$ for the boiling potassium was obtained for a heat of evaporization of potassium at 29 psia of $842 \mathrm{Btu} / \mathrm{Ib}$.

The flow rate of potassium vapor to the potassium condenser was evaluated from the relation

$$
Q\left(1-\eta_{k}\right)=W_{k}(I-F) \Delta H,
$$

where

$$
\begin{aligned}
Q & =\text { heat generation rate in reactor, Btu/sec, } \\
\eta_{k} & =\text { efficiency of potassium vapor cycle, } \\
F & =\text { fraction of vapor extracted for feed heater, } \\
\Delta H & =\text { heat of condensation for potassium, Btu/lb, } \\
W_{k} & =\text { potassium vapor flow rate, } 1 \mathrm{~b} / \mathrm{sec} .
\end{aligned}
$$

Evaluating Eq. (5) gives

$$
0.946 \times 10^{6}(1-0.156)=W_{k}(1-0.0865) \times 881,
$$

and thus the flow rate of potassium vapor to the condenser is $W_{k}=971$ $\mathrm{lb} / \mathrm{sec}$. This quantity is the total amount of potassium that will condense on the tubes of the steam generator and the two steam reheaters. The amount of condensate for each of these units will be proportional to the fraction of the total heat transferred in each case. Assuming about $16 \%$ extraction for feedwater heating before the steam enters each of the reheaters, the fractional distribution of power input to the steam boiler and the reheaters was estimated. The results are presented in Table 8.

Table 8. Distribution of Power to Steam Boiler and Reheaters

\begin{tabular}{lcccc}
\hline Unit & $\begin{array}{c}\text { Heat of } \\
\text { Condensation } \\
\text { for Steam, } \Delta \mathrm{H} \\
(\mathrm{Btu} / \mathrm{Ib})\end{array}$ & $\begin{array}{c}\text { Fractional } \\
\text { Weight Flow } \\
\text { Kate of } \\
\text { Steam, W }\end{array}$ & $\Delta \mathrm{H} \times \mathrm{W}$ & $\begin{array}{c}\text { Power } \\
\text { Distribution }\end{array}$ \\
\hline Steam boiler & 886.0 & 1.0 & 886 & 0.775 \\
Reheater 1 & 161.0 & 0.84 & 135 & 0.118 \\
Reheater 2 & 180.2 & 0.68 & 123 & 0.107 \\
\hline
\end{tabular}


Based on the values of Table 8 , the rates of condensation of potassium on the steam generator, reheater 1 , and reheater 2 are 752, 115, and $104 \mathrm{lb} / \mathrm{sec}$, respectively. The steam flow rates through these units can be obtained directly by multiplying the rate of condensation of potassium for each of these units by the ratio of the latent heat of condensation of potassium to the enthalpy rise of steam in each unit. In reheater 1 , for instance, the steam flow rate is

$$
\frac{881.0}{161.0} \times 115=6301 \mathrm{~b} / \mathrm{sec}
$$

The total flow rates thus calculated are listed in Table 7.

Heat Transfer and Pressure Urop

The general relation for determining pressure drop through circular passages is

$$
\Delta \mathrm{P}=\mathrm{f} \frac{\mathrm{G}^{2}}{2 \mathrm{~g} \rho} \frac{\mathrm{L}}{\mathrm{d}_{\mathrm{e}}} .
$$

If Eq. (6) is rearranged, and the units for pressure drop, flow rate, and the tube diameter are converted to conventional energy units,

$$
G^{\prime}=27.5\left(\frac{\rho d_{e} \Delta \mathrm{P}^{\prime \prime}}{f L}\right)^{1 / 2}
$$

where

$$
\begin{aligned}
G^{\prime} & =\text { flow rate, } 1 \mathrm{~b} / \mathrm{ft}^{2} \cdot \mathrm{sec}, \\
\Delta \mathrm{F}^{\prime \prime} & =\text { prcssure drop, psia, } \\
\mathrm{d}_{\mathrm{e}}= & \text { equivalent passage didmeter, in. } \\
\mathrm{L}= & \text { tube length, } \mathrm{ft}, \\
\rho= & \text { density, } \mathrm{lb} / \mathrm{ft} \mathrm{t}^{3}, \\
\mathrm{f}= & \text { friction factor based on equivalent hydraulic diämeter, dimen- } \\
& \text { sionless. }
\end{aligned}
$$

Another relation can be obtained from heat transfer considerations by equating the heat carried by the tube side fluid to the heat transferred across 
the tube:

$$
\frac{\pi \mathrm{d}_{i}^{2}}{4144} G_{i}^{\prime} c_{p i} \delta t_{i}=U L \frac{\pi \bar{d}}{12} \Delta t
$$

where the subscript (i) refers to the flows inside the tubes, and

$$
\begin{aligned}
d_{i} & =\text { tube inside diameter, in., } \\
\bar{d} & =\frac{d_{i}+d_{0}}{2}, \text { in. (where } d_{0} \text { is tube outside diameter), } \\
c_{p i} & =\text { specific heat, } \mathrm{Btu} / \mathrm{lb} \cdot{ }^{\circ} \mathrm{F}, \\
G_{i}^{\prime} & =\text { mass flow rate, } \mathrm{lb} / \mathrm{ft}^{2} \cdot \mathrm{sec}, \\
8 t_{i} & =\text { temperature rlse or drop of tube side fluid, }{ }^{\circ} \mathrm{F}, \\
U & =\text { overall heat transfer coefficient, Btu/hr.ft }{ }^{2} \cdot{ }^{\circ} \mathrm{F}, \\
\Delta t & =\text { mean temperature difference between the tube side and shell side } \\
& \text { fluids, }{ }^{\circ} \mathrm{F},
\end{aligned}
$$

or, solving for $\Delta t$,

$$
\Delta t=75 \frac{a_{i}^{2}}{d} \frac{c_{p i} \delta t_{i}}{U L} G_{i}^{\prime} .
$$

The tube length that will satisfy both the heat transfer and the pressure drop relations given above (i.e., Eqs. 7 and 8 ) may be found for typical conditions of interest. Suitable values may be chosen for $f, \Delta \mathrm{P}^{\prime \prime}$, $\mathrm{d}_{e}$, and $\rho$ for both the tube side and the shell side fluids and the values of $G^{\prime}$ evaluated from Eq. (7) for an arbitrarily chosen value of $\mathrm{L}$. The heat transfer coefficients for the tube-side and shell-side fluids, $h_{i}$ and $h_{0}$, can then be calculated using the flow rates obtained. The overall heat transfer coneficient is given by:

$$
\frac{1}{U}=\frac{1}{h_{0}}+\frac{1}{h_{i}} \text {. }
$$


A constant value of $3000 \mathrm{Btu} / \mathrm{hr} \cdot \mathrm{ft}^{2}{ }^{\circ} \mathrm{F}$ was chosen for $\mathrm{h}_{\mathrm{o}}$ for boiling potassium; ${ }^{18}$ the values of $h_{i}$ for the salt were calculated; and the values obtained for $U$ were substituted in Eq. (8) to obtain $\Delta$ t.

The calculations were repeated for different tube lengths, and a curve was plotted to give $\mathrm{L}$ as a function of $\Delta t$. The tube length corresponding to the design temperature difference in the heat exchanger will satisfy all the conditions assumed. The external and internal mass flow rates $G_{0}^{\prime}$ and $G_{i}^{\prime}$ corresponding to the above tube length may be obtained by interpolation. The flow rate per tube may be obtained by multiplying the mass flow rate by the flow area per tube. The total number of tubes was obtained by dividing the total mass flow rate of the fluid by the mass flow rate per tube. The results of these calculations are presented in Table 7.

It was assumed that the tubes would be arranged in the form of U-tube bundles. Since the total cross-sectional area of the bundles, as shown in Table 7, was too large for each heat exchanger to be arranged in a single unit, the number of units chosen for each type of tube bundle is also given, as is the approximate diameter of an equivalent round tubebundle unit and the number of U-tubes in each unit.

The physical properties of the fluids used in performing these heat transfer and pressure drop calculations are given in Table 9 . The basic relations used in estimating values for the heat transfer coef't'icient, $h$, are summarized below:

For fuel No. 133:

$$
\mathrm{Nu}=0.00484 \mathrm{Re}^{0.932} \operatorname{Pr} 0.4, \quad \text { (from ref. 21) }
$$

and for 0.295-in.-ID tubes,

$$
h=10.7 \frac{\operatorname{Pr}^{0.4} \mathrm{k}}{\mu^{0.932}}\left(G^{\prime}\right)^{0.932}
$$

For the temperatures considered,

$$
\mathrm{h}=2.12\left(G^{\prime}\right)^{0.932}
$$


Table 9. Physical Properties of Fuel, Inert Salt, and Supercritical Steam

\begin{tabular}{|c|c|c|c|c|}
\hline & $\begin{array}{l}\text { Fuel } \\
\text { No. } 133^{a}\end{array}$ & $\begin{array}{l}\text { Salt } \\
\text { No. } 12^{b}\end{array}$ & $\begin{array}{r}\text { Supercr } \\
\text { Ste }\end{array}$ & $\begin{array}{l}\text { itical } \\
\text { am }\end{array}$ \\
\hline $\begin{array}{l}\text { Operating temperature, }{ }^{\circ} \mathrm{F} \\
\text { Operating pressure, psi } \\
\text { Density, o, lb/ft }{ }^{3} \\
\text { Specific heat, }{ }^{\mathrm{p}} \mathrm{Btu} / \mathrm{lb} \cdot{ }^{\circ} \mathrm{F} \\
\text { Viscosity, } \mu, \mathrm{lb} / \mathrm{ft} \cdot \mathrm{hr} \\
\text { Thermal conductivity, } \mathrm{k}, \mathrm{Btu} / \mathrm{hr} \cdot \mathrm{ft} \cdot{ }^{\circ} \mathrm{F} \\
\text { Prandtl. No., } \mathrm{Pr}=\mathrm{c}_{\mathrm{p}} \mu / \mathrm{k}\end{array}$ & $\begin{array}{l}1700 \\
70 \\
218^{\mathrm{c}} \\
0.33^{\mathrm{c}} \\
16.1 \mathrm{e} \\
1.75^{\mathrm{e}} \\
3.04\end{array}$ & $\begin{array}{l}1700 \\
70 \\
117^{\mathrm{d}} \\
0.45^{\mathrm{d}} \\
5.0^{\mathrm{d}} \\
2.6^{\mathrm{d}} \\
0.8^{\mathrm{d}} \mathrm{d}\end{array}$ & $\begin{array}{l}1000 \\
4000 \\
0.83 \\
0.122 \\
0.0372 \\
2.72\end{array}$ & $\begin{array}{l}800 \\
4000 \\
2.00 \\
0.131 \\
0.0355 \\
7.35\end{array}$ \\
\hline 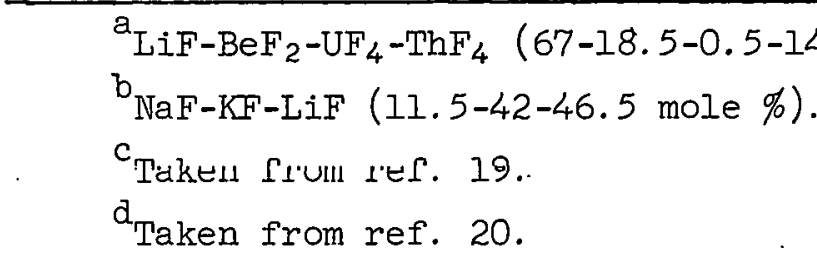 & 4 mole $\%$ & & & \\
\hline
\end{tabular}

For salt No. 12:

$$
\mathrm{Nu}=0.023 \mathrm{Re}^{0.8} \operatorname{Pr} 0.4
$$

and for 0.295-in. -ID tubes and the temperatures considered,

$$
h=11.6\left(G^{\prime}\right)^{0.8}
$$

For the steam in the superheater:

$$
\mathrm{Nu}=0.023 \times \operatorname{Re}^{0.8} \operatorname{Pr}^{0.4},
$$

and for 0.375-in. -ID tubes and 4000 psia steam,

$$
h=C\left(G^{\prime}\right)^{0.8}
$$

In this expression for $h$,

$$
\begin{aligned}
\mathrm{C} & =12.7 \text { at } 800^{\circ} \mathrm{F} \\
& =10.4 \text { at } 900^{\circ} \mathrm{F} \\
& =9.65 \text { a } 1000^{\circ} \mathrm{F} .
\end{aligned}
$$


The Main Piping

A summary of the size, weight, and length of the main piping between the principal units is presented in Table 10. Included in this table are the temperature and pressure conditions, the flow rates, and the estimated pressure drops through the straight portions of the piping. A $21 / 2 \%$ $\mathrm{Cr}-1 \%$ Mo steel was assumed for all the steam lines and columbium for the salt lines. The last row of the table summarizes the approximate weights of pipe material for each system considered.

\section{Power Distribution}

Approximately one-third of the total power is generated by the potassium turbine and the rest by the steam turbines. The power required for the boiler feed pumps was estimated to be $12 \mathrm{Mw}$, while that for the auxiliaries over the boiler feed was taken as $4 \mathrm{Mw}$. Thus, of the $574 \mathrm{Mw}$ of gross power generated, the net power output of the plant would be about $558 \mathrm{Mw}$. 
Table 10. Pressures, Temperatures, Lengths, Sizes, and Flow Rates of Main Piping

\begin{tabular}{|c|c|c|c|c|c|c|c|}
\hline & $\begin{array}{l}\text { From Salt Heat } \\
\text { Exchanger to } \\
\text { Potassium } \\
\text { Boiler }\end{array}$ & $\begin{array}{l}\text { From Potassium } \\
\text { Boiler to } \\
\text { Salt Heat } \\
\text { Exchanger }\end{array}$ & $\begin{array}{l}\text { From Steam } \\
\text { Boiler to } \\
\text { Very-High- } \\
\text { Pressure } \\
\text { Turbine }\end{array}$ & $\begin{array}{l}\text { From Very- } \\
\text { High-Pressure } \\
\text { T:rrbine to } \\
\text { Reheater } 1\end{array}$ & $\begin{array}{c}\text { From Reheater } 1 \\
\text { to High- } \\
\text { Pressure } \\
\text { Turbine }\end{array}$ & $\begin{array}{l}\text { From High- } \\
\text { Pressure } \\
\text { Turbine to } \\
\text { Reheater } 2\end{array}$ & $\begin{array}{c}\text { From } \\
\text { Reineater } 2 \text { to } \\
\text { Intermediate- } \\
\text { Pressure } \\
\text { Turbine }\end{array}$ \\
\hline Fluid & Salt ho. 12 & Salt No. 12 & Steam & Steam & Steam & Steam & Steam \\
\hline Pipe material & Columbrium & Columbium & Steela & Steela & Steela & Steela & Steela \\
\hline Pipe size; in. & $\begin{array}{l}12 \mathrm{IL}, 1 / 4 \\
\text { wall }\end{array}$ & $\begin{array}{l}12 \text { ID, } 1 / 4 \\
\text { wall }\end{array}$ & $\begin{array}{l}5 \text { ID, } 2.4 \\
\text { wall }\end{array}$ & $\begin{array}{l}10 \text { ID, } 1 \\
\text { wall }\end{array}$ & $\begin{array}{l}10 \text { ID, } 1.56 \\
\text { wall }\end{array}$ & $\begin{array}{l}20 \text { ID, } 0.875 \\
\text { wall }\end{array}$ & $\begin{array}{l}20 \mathrm{ID}, 0.875 \\
\text { wall }\end{array}$ \\
\hline Total flow rate: $1 \mathrm{~b} / \mathrm{sec}$ & $2 i, 000$ & 21,000 & 746 & 630 & 639 & 508 & 508 \\
\hline Peak pressure, psia & 70 & 70 & 4000 & 1133 & 1043 & 263 & 251 \\
\hline Peak temperature, ${ }^{\circ} \mathrm{F}$ & 1700 & 1600 & 1050 & 786 & 1050 & 705 & 1050 \\
\hline Number of lines & 12 & 12 & 8 & 4 & 4 & 4 & 4 \\
\hline Flow rate per line, ib/sec & 1750 & 1750 & 93 & 158 & 158 & 127 & 127 \\
\hline Density, $1 b / f t^{3}$ & 117 & 117 & 5.08 & 1.69 & 1.22 & 0.385 & 0.280 \\
\hline Flow area per line, $\mathrm{ft}^{2}$ & 0.785 & 0.785 & 0.1385 & 0.545 & 0.545 & 2.180 & 2.180 \\
\hline Flow velocity, $t / \mathrm{sec}$ & 16.0 & 16.0 & 129 & 170 & 233 & 151 & 208 \\
\hline Mean length per line, ft & 50 & 50 & 90 & 90 & 95 & 90 & 110 \\
\hline Pressure drop, psi & 7 & 7 & 94 & 27 & 39 & 3 & 5 \\
\hline Total length of piping, ft & 600 & 600 & 720 & 360 & 380 & 360 & 440 \\
\hline Weight per unit length, $1 \mathrm{~b} / \mathrm{ft}$ & 33 & 33 & 200 & 110 & 170 & 190 & 190 \\
\hline Total weight of piping, lb & 19,800 & 19,800 & 144,0010 & 39,500 & 64,800 & 68,500 & 83,500 \\
\hline
\end{tabular}

$a_{2} 1 / 2 \%$ cr-1\% Mo steel. 
THIS PAGE

\section{WAS INTENTIONALLY LEFT BLANK}




\section{$\underline{\text { References }}$}

1. C. W. E. Clarke and W. P. Gavit, "The Expanding Market for Electric Power," Mech. Eng., p. 483, 1954.

2. J. B. McClure and A. G. Mellor, "Electric Power Generation - Past, Present, and Future," Mech. Eng., p. 521, 1956.

3. W. L. R. Enmet, "The Emmet Mercury-Vapor Process," Trans. ASME, 46: 253 (1924).

4. W. L. R. Emmet, "Mercury Vapor for Central Station Power, "Mech. Eng., p. 351, 1941 .

5. A. R. Smith and E. S. Thompson, "The Mercury Vapor Process, "Trans. ASME, 64:625 (1942).

6. H. N. Hackett, "Mercury-Steam Power Plants," Mech. Eng., p. 559, 1951; p. 166, 1952.

7. H. N. Hackett and 'D. Douglass, "Modern Mercury-Unit Power Plant Design," Trans. ASME, 72: 89 (1950).

8. Federal Power Commission, Steam-Electric Plant Construction Cost and Annual Production Expenses, p. 50, 1950.

9. U.S. Department of Interior, 1961 Minerals Yearbook, Vol. I, Metals and Minerals (except Fuels).

10. E. C. King, "The Reaction of $\mathrm{NaK}$ and $\mathrm{N}_{2} \mathrm{O}$, Tech. Rept. XII, Mine Safety Appliances Co., Contract N9 onr-85801, January 1952.

11. S. N. Fialà, "First Commercial Supercritical Pressure Steam-Electric Generating Unit for the Philo Plant," Trans. ASME, 79: 389 (1957).

12. W. H. Rowand and A. M. Frendberg, "Frist Commercial SupercriticalPressure Steum," Trans. ABME, 79: 1410 (1957).

1.3. J. H, Harlow, "Engineering the Eddystone Plant for 5000 lb $1200-d e g$ Steam," Trans. ASME, 79: 1410 (1957).

14. W. E. Trumpler, Jr., et al., "Development Associated with the Superpressure Turbine for Eddystone Station Unit No. '1," Trans. ASME, 8'2: $2866(1960)$.

15. Federal Power Commission, Steam-Electric Plant Construction Cost and Annual Production Expenses, 1960.

16. Federal Power Commission, Steam-Electric Plant Construction Cost and Annual Production Expenses, 14th Annual Sup., 1961. 
17. W. D. Weatherford et al., "Properties of Inorganic Energy Conversion and Heat Transfer Fluids for Space Applications," WADD Tech. Rept. 61-96, March 1961.

18. H. W. Hoffman and A. I. Krakoviak, "Forced Convection Saturation Boiling of. Potassium at Near Atmospheric Pressure," Proceedings of the 1962 High Temperature Liquid Metal Heat Transfer Technology Meeting, pp. 182-203, USAEC Report BNL-756, Brookhaven National Laboratory.

19. Oak Ridge National Laboratory, "MSRP Prog. Rep. for Period from March 1 to August 31, 1961," USAEC Report ORNL-3215, pp. 132-134.

20. S. I. Cohen et al., "A Physical Property Summary for ANP Fluoride Mixtures," USAEC Report ORNL-2150, Oak Ridge National Laboratory, August 1956.

21. R. B. Briggs, "Molten-Salt Reactor Program Progress Report, for Period. from Aug. 1, 1960 to Feb. 28, 1961," p. 141, USAEC Report URNL-3122, Oak Ridge National Laboratory. 


\author{
ORNL -3584 \\ UC-80 - Reactor Technology \\ TID-4500 (29th ed.)
}

\section{Internal Distribution}
1. R. G. Affel
2. S. E. Beall
3. R. B. Briggs
4. R. D. Bundy
5. W. I. Carter
6. C. E. Center
7. C. J. Claffey
8. C. W. Collins
9. R. G. Donnelly
10. A. P. Fraas
1l. W. R. Gall
12. R. G. Gilliland
1.3. N. Hilvety
14. H. W. Hoffman
15. W. R. Huntley
16. G. W. Keilholtz
17. P. A. Knadt
18. T. S. Kress
19. J. A. Lane
20. C. E. Larson
21. M. E. LaVerne
22. A. Litman
23. M. I. Lundin
24. H. G. MacPherson

25. H. F. McDuffie

26. J. R. McWherter

27. S. A. Reed '

28. M. W. Rosenthal

29. G. Samuels

30. H. W. Savage

31. A. W. Savolainen

32. J. E. Savolainen

33. M. J. Skinner

34. I. Spiewak

35. J. A. Swartout

36. J. R. Tallackson

37. W. C. Thurber

38. D. B. Trauger

39. R. Van Winkle

40. A. M. Weinberg

41. Gale Young

42. F. C. Zapp

43. J. Zasler

44-46. Central Research Library

47-48. Y-12 Document Reference Section

49-94. Laboratory Records Department

95. Laboratory Records, R.C.

\title{
External Distribution
}

y6. W. R. Chambers, University of Tennessee

97. M. N. Ozisik, North Carolina State College, Kaleigh, North Carolina

98. Division of Research and Development, AEC, ORO

99-100. Reactor Division, AEC, ORO

101-707. Given distribution as shown in TID-4500 (29th ed.) under Reactor Technology Category ( 75 copies OTS) 